\title{
Pseudomonas aeruginosa biofilm is a potent inducer of phagocyte hyperinflammation
}

\author{
Marta Ciszek-Lenda ${ }^{1}$ Magdalena Strus ${ }^{2} \cdot$ Maria Walczewska $^{1} \cdot$ Grzegorz Majka $^{1} \cdot$ Agnieszka Machul-Żwirbla $^{2}$. \\ Diana Mikołajczyk ${ }^{2} \cdot$ Sabina Górska ${ }^{3} \cdot$ Andrzej Gamian $^{3}$ • Benjamin Chain ${ }^{4}$ · Janusz Marcinkiewicz ${ }^{1}$ (1)
}

Received: 7 March 2019 / Accepted: 10 March 2019 / Published online: 18 March 2019

(c) The Author(s) 2019

\begin{abstract}
Objective Pseudomonas aeruginosa effectively facilitate resistance to phagocyte killing by biofilm formation. However, the cross talk between biofilm components and phagocytes is still unclear. We hypothesize that a biofilm provides a concentrated extracellular source of LPS, DNA and exopolysaccharides (EPS), which polarize neighbouring phagocytes into an adverse hyperinflammatory state of activation.

Methods We measured the release of a panel of mediators produced in vitro by murine neutrophils and macrophages exposed to various biofilm components of $P$. aeruginosa cultures.

Results We found that conditioned media from a high biofilm-producing strain of $P$. aeruginosa, PAR5, accumulated high concentrations of extracellular bacterial LPS, DNA and EPS by $72 \mathrm{~h}$. These conditioned media induced phagocytes to release a hyperinflammatory pattern of mediators, with enhanced levels of TNF- $\alpha$, IL-6, IL12p40, PGE 2 and NO. Moreover, the phagocytes also upregulated COX-2 and iNOS with no influence on the expression of arginase- 1 .

Conclusions Phagocytes exposed to biofilm microenvironment, called by us biofilm-associated neutrophils/macrophages (BANs/BAMs), display secretory properties similar to that of N1/M1-type phagocytes. These results suggest that in vivo high concentrations of LPS and DNA, trapped in biofilm by EPS, might convert infiltrating phagocytes into cells responsible for tissue injury without direct contact with bacteria and phagocytosis.
\end{abstract}

Keywords Biofilm $\cdot$ Hyperinflammation $\cdot$ Neutrophils $\cdot$ P. aeruginos $a \cdot$ LPS $\cdot$ DNA

\section{Introduction}

Pseudomonas aeruginosa is an opportunistic human pathogen that preferentially attacks immunocompromised patients and causes diverse chronic infections, such as severe nosocomial pneumonia and non-healing wounds [1-3]. Chronic lung infection with $P$. aeruginosa is a highly

Responsible Editor: John Di Battista.

Janusz Marcinkiewicz

mmmarcin@cyf-kr.edu.pl

1 Chair of Immunology, Jagiellonian University Medical College, Kraków, Poland

2 Chair of Microbiology, Jagiellonian University Medical College, Kraków, Poland

3 Ludwik Hirszfeld Institute of Immunology and Experimental Therapy, Polish Academy of Sciences, Wrocław, Poland

4 Division of Infection and Immunity, UCL, London, UK morbid complication that is particularly found in patients with cystic fibrosis (CF) [4]. P. aeruginosa has strong pathogenicity and resistance to antibiotic therapy, largely due to its inherent biofilm-forming capacity [5]. Bacterial infections associated with biofilm formation are characterized by severe and progressive chronic inflammation, massive neutrophil infiltration but paradoxical resistance to immune attack [6, 7]. Two explanations for the increased resistance of biofilm-forming bacteria have been put forth: (1) bacterial cells may be hidden in the biofilm matrix, such that their contact with antibacterial agents or immune cells is reduced; or (2) infiltrating phagocytes may be less effective in killing biofilm-hidden pathogens [8].

Mechanisms of tissue injury and chronic inflammation during chronic $P$. aeruginosa infections may reflect direct cytotoxic effects of $P$. aeruginosa toxins (e.g., rhamnolipids) and indirect effects of immunopathogenic mediators (e.g., NO, ROS, TNF- $\alpha$ ) released from infiltrating phagocytes [9]. Biofilm formation is characterized by pronounced metabolic 

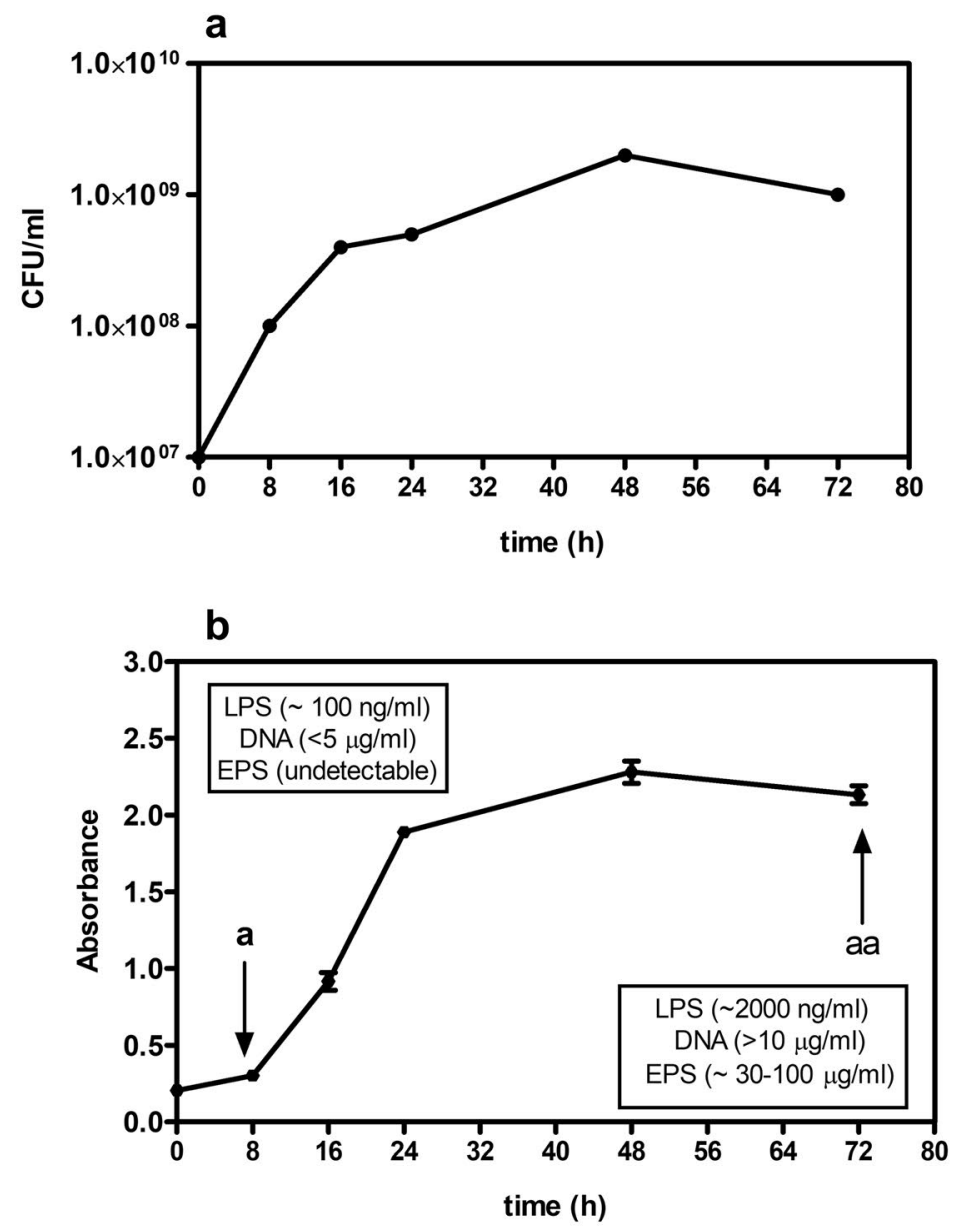

C
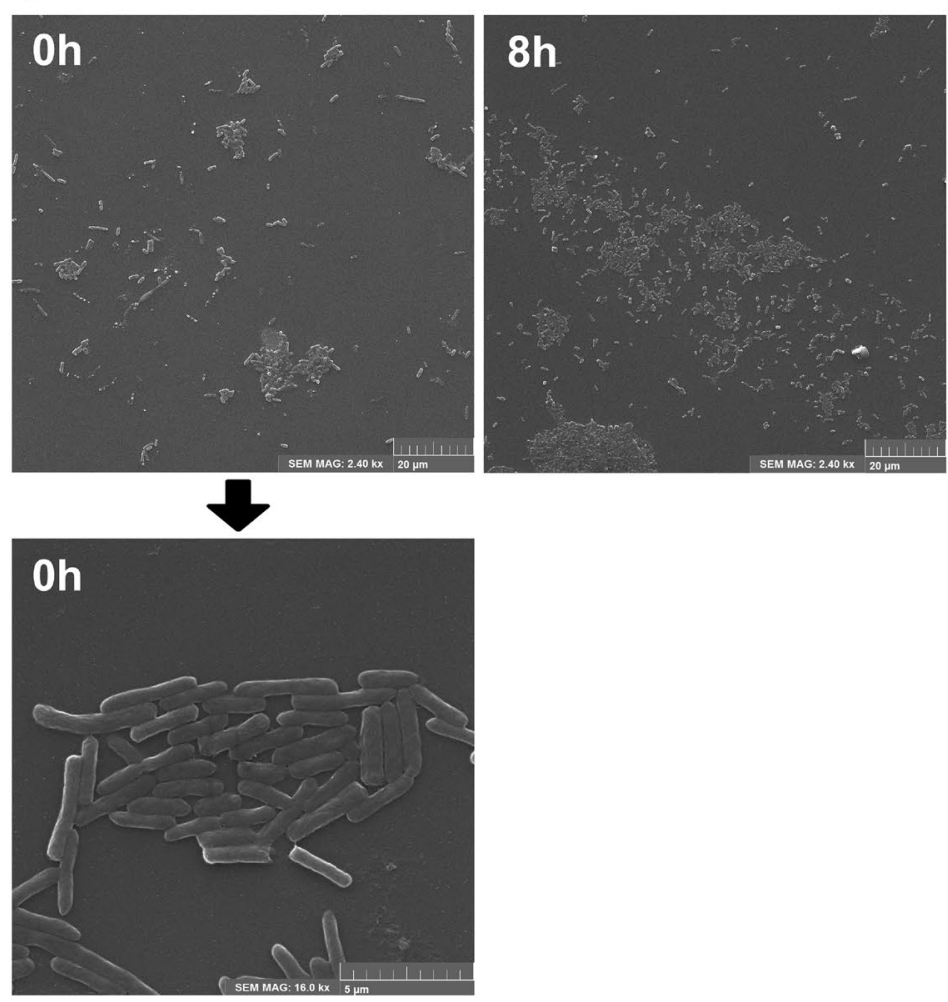
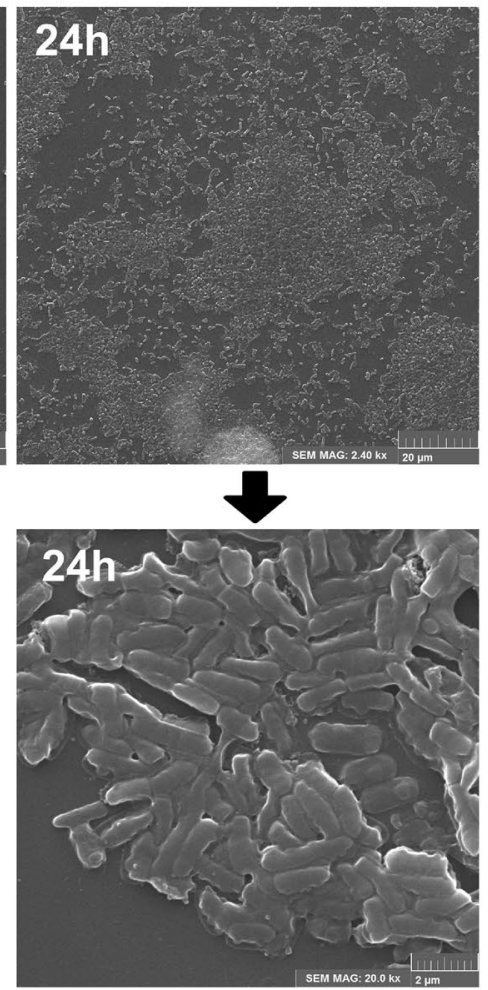
4Fig. 1 The representative record of kinetics of biofilm formation by PAR5. a Density of PAR5 population at the indicated points of time is expressed in CFU of sessile cells per ml. The culture started with the bacterial suspension at a density of $10^{7} \mathrm{CFU} / \mathrm{ml}$. b Building of biofilm matrix. Congo red staining was used for measuring biofilm formation (EPS accumulation). Plot depicts mean values \pm SD of absorbance $(\lambda=492 \mathrm{~nm})$. The mean was calculated on the basis of three independent experiments $(n=3)$. ${ }^{\text {a }} 8$-h PAR5 planktonic bacteria cell attachment and the beginning of biofilm formation ${ }^{\text {aa }} 72 \mathrm{~h}-$ mature biofilm. At these time points of the culture, the concentration of DNA, LPS and EPS in bacterial conditioned media is shown. c SEM of: 0-h PAR (free-floating planktonic bacteria); 8-h PAR5 (cluster of planktonic bacteria, the beginning of biofilm formation); 24-h PAR5 (conglomerate cluster of bacteria-early biofilm)

changes of sessile bacteria and secretion of strain-specific extracellular polymeric substances, including exopolysaccharides (EPSs), DNA, LPS and proteins [10-12]. These biofilm matrix components may, therefore, provide a concentrated extracellular source of PAMPS, which activate and polarize biofilm-infiltrating neutrophils and macrophages into more aggressive proinflammatory subtypes [13, 14]. Biofilm may, therefore, both protect bacteria from killing, yet activate hyperinflammation. It has been well documented that hyperinflammatory response, the effect of activation of neutrophils and macrophages with limited access to targets, does favor chronic inflammation without effective bacterial clearance [15-18]. Such reaction was also named as "frustrated phagocytosis" [19, 20].

We hypothesize that neutrophils and macrophages, upon contact with active biofilm matrix components such as found in a biofilm environment, polarize into biofilm-associated neutrophils (BANs) and biofilm-associated macrophages (BAMs). Based on previous studies [15, 21, 22], we suggest that these phagocytes will be of hyperinflammatory phenotype, sometimes referred to as N1/M1 phenotypes. We explore this hypothesis by examining the inflammatory phenotype of macrophages and neutrophils exposed to $P$. aeruginosa extracellular products produced early $(8 \mathrm{~h})$ in culture, when biofilm production is just initiated, and $P$. aeruginosa extracellular products produced late $(72 \mathrm{~h})$, when massive biofilm production takes place.

\section{Materials and methods}

\section{Characterization of $P$. aeruginosa strain PAR5}

All experiments in this study were performed on mucoid $P$. aeruginosa strain coded as PAR5, which was selected from a larger collection out of 20 P. aeruginosa strains isolated from patients with chronic non-healing diabetic foot infections. PAR5 has the ability to form the largest amount of biofilm mass compared to the same population of other strains from the collection [23, 24].
Growth conditions and measurement of biofilm formation by PAR5

The initial culture of PAR5 was propagated in $10 \mathrm{ml}$ of tryptic soy broth (TSB, Difco) at $37{ }^{\circ} \mathrm{C}$ for $24 \mathrm{~h}$ under aerobic conditions. After cultivation, bacteria were centrifuged for $10 \mathrm{~min}$ at $500 \mathrm{~g}$ and washed with $10 \mathrm{ml}$ of phosphate buffered saline (PBS, pH 7.4, Sigma-Aldrich). Bacterial count, confirmed by decimal dilutions, reached $1 \times 10^{8} \mathrm{CFU} / \mathrm{ml}$.

Biofilm quantity (total mass of bacterial polysaccharides) was measured in sterile plastic 96-well plates with adherent surface (Greiner Bio-One) using Congo red dye according to a modified procedure described by Reuter et al. [25]. Briefly, $20 \mu \mathrm{l}$ of fresh culture of the bacterial suspensions, prepared as described above, was added to each well followed with $180 \mu \mathrm{l}$ of sterile TSB. Final concentration of the bacteria was $1 \times 10^{7} \mathrm{CFU} / \mathrm{ml}$. The plates were centrifuged for $10 \mathrm{~min}$ at $500 \mathrm{~g}$ to sediment bacteria at the bottom of each well. Bacteria were then incubated for $72 \mathrm{~h}\left(37^{\circ} \mathrm{C}\right.$, aerobic conditions). At different time points of the culture (0, 8, 16, 24, 48 and $72 \mathrm{~h}$ ), the plates were centrifuged, the culture medium was gently removed from wells and, immediately, $200 \mu \mathrm{l}$ of $0.1 \%$ Congo red solution was added. The plates were left for $30 \mathrm{~min}$ at room temperature (RT) and washed twice with buffered saline to remove unbound dye. Absorbance was measured at $\lambda=492 \mathrm{~nm}$ wavelength using a spectrophotometer (Awareness Technology Inc.). All measurements were performed in triplicates and mean values \pm SD were given. The representative record of kinetics of bacteria growth and biofilm formation by PAR5 is shown in Fig. 1a, b. Moreover, SEM images of PAR5 cultures $(0,8$, and $24 \mathrm{~h})$ were prepared (Fig. 1c). Bacterial morphology was examined under a scanning electron microscope (TESCAN). Coverslips were placed in a 12-well plate and treated with poly-L-lysine to enhance further bacterial cell adhesion. Glass slides were immersed in bacterial suspensions for 0,8 , and $24 \mathrm{~h}$. Then, $1 \mathrm{ml}$ of fixing buffer (sodium cacodylate in $2.5 \%$ glutaraldehyde and $0.1 \mathrm{M}$ sucrose) was added and the slides were incubated for $1.5 \mathrm{~h}$ at $37^{\circ} \mathrm{C}$. A dehydration procedure was applied in a gradient of methanol. Dried samples were sputtered with a 20-nm gold layer (Quorum, Q150R S) to facilitate SEM visualization [26].

\section{PAR5 culture and preparation of bacterial-conditioned media}

$1 \mathrm{ml}$ of the bacterial suspension, prepared as described above, was added to sterile tubes, each containing $9 \mathrm{ml}$ of fresh TSB broth, and cultured for either $8 \mathrm{~h}$ (planktonic stage of PAR5 cultures) or $72 \mathrm{~h}$ (mature biofilm stage of PAR5 cultures). The bacteria were grown under aerobic conditions without shaking at $37^{\circ} \mathrm{C}$. 


\section{PAR5-8 $\mathrm{h}$}

After $8 \mathrm{~h}$, the number of PAR5 cells present in the culture was estimated by making an appropriate decimal dilution of the bacteria in PBS and counting the bacterial colonies plated on McConkey agar (Oxoid) (Fig. 1a). The remaining volume of the PAR5 culture was centrifuged for $10 \mathrm{~min}$ at $500 \mathrm{~g}$. Supernatant was transferred to a fresh tube, filtered with a $0.22-\mu \mathrm{m}$ Millipore membrane, and stored at $4{ }^{\circ} \mathrm{C}$ until needed. This solution was labeled as BCM- $8 \mathrm{~h}$ (planktonic bacterial-conditioned medium). The pellet of PAR5-8 $\mathrm{h}$ bacterial cells was washed with $10 \mathrm{ml}$ PBS (pH 7.4) and stored at $4{ }^{\circ} \mathrm{C}$.

\section{PAR5-72 h}

The above steps were repeated after $72 \mathrm{~h}$ to collect PAR5$72 \mathrm{~h}$ bacterial cells and BCM-72 h (mature biofilm-conditioned medium) for further studies.

\section{Killing P. aeruginosa PAR5 bacterial cells}

PAR5 pellets originating from the 8 - and 72 -h cultures were treated thrice with high temperature $\left(121^{\circ} \mathrm{C}\right)$ at 0.3 bars in the ASVE-ELMI ESS-207 SMS steam sterilizer. The followup culture was verified to be sterile.

\section{Measurement of bacterial DNA in bacterial condition media}

Extracellular bacterial DNA was isolated and purified from bacterial-conditioned media, according to the manufacturer's protocol (Genomic Mini, A\&A Biotechnology, Poland). Concentration of purified, specific-density DNA was determined with a spectrophotometer (DS-11; DeNovix Co.) at a wavelength of $260 \mathrm{~nm}$.

\section{Measurement of LPS concentration in bacterial-conditioned media}

Level of LPS in tested samples was estimated by use of QCL-1000 Chromogenic LAL test (Lonza) according to the manufacturer's protocol. QCL-1000 is an assay for the detection of Gram-negative bacterial endotoxin.

\section{DNA extraction}

The bacterial cells from $72 \mathrm{~h}$ grown culture were harvested (8000 rpm, $10^{\circ} \mathrm{C}, 15 \mathrm{~min}$ ). The pellet was washed twice by PBS and again harvested. $0.25 \mathrm{ml}$ of $10 \mathrm{mM}$ Tris- $\mathrm{HCl}$ (pH 8) and $2.5 \mathrm{mg} / \mathrm{ml}$ of lysozyme were added and incubated at $37{ }^{\circ} \mathrm{C}$ for $2 \mathrm{~h}$. Then, $0.5 \mathrm{ml}$ of lysis buffer $(50 \mathrm{mM}$ Tris, $100 \mathrm{mM}$ EDTA, 1\% SDS, $\mathrm{pH} 8$ ) and $1 \mathrm{mg} / \mathrm{ml}$ of
proteinase-K were added and incubated at $50{ }^{\circ} \mathrm{C}$ for $2 \mathrm{~h}$ in a water bath. The digestion with proteinase-K was followed by addition of $0.5 \mathrm{ml}$ of phenol:chloroform (1:1). The samples were mixed gently for $3 \mathrm{~min}$ and harvested $(14,000 \mathrm{rpm}$, $\left.4{ }^{\circ} \mathrm{C}, 15 \mathrm{~min}\right)$. The upper layer was transferred in fresh tube and extracted with chloroform:isoamyl alcohol (24:1) by the centrifugation at $14,000 \mathrm{rpm}$ on $4{ }^{\circ} \mathrm{C}$ for $15 \mathrm{~min}$. This step was repeated. The supernatant was precipitated with twice volume of ethanol and left till the precipitation was settled down. DNA was collected by centrifuging at $14,000 \mathrm{rpm}$, on $4{ }^{\circ} \mathrm{C}$ for $15 \mathrm{~min}$ and dried. The pellet was suspended in $10 \mathrm{mM}$ Tris- $\mathrm{HCl}(\mathrm{pH} 8)$ and $1 \mathrm{mM}$ EDTA $(\mathrm{pH} 8)$ buffer and incubated at $45{ }^{\circ} \mathrm{C}$ in a water bath for $3 \mathrm{~h}$. The quality of DNA was checked using DS-11 spectrophotometer (DeNovix).

\section{LPS isolation}

LPS was isolated using hot phenol/water method and purified as described by Westphal et al. [27]. Quantity of LPS was measured after the sample lyophilisation.

\section{EPS isolation}

EPS was isolated as described previously [28]. The obtained material was purified by DNAse, RNAse and protease. Total saccharide concentration was measured by phenol sulfuric acid method according to Dubois's method [29].

\section{Fractionation of bacterial-conditioned media}

BCM-72 $\mathrm{h}$ in volumes of $2 \mathrm{ml}$ was placed in Sartorius fractionation columns (Vivacon 2) with molecular weight (MW) cut-off of $10 \mathrm{kDa}$ and centrifuged for $30 \mathrm{~min}$ at $3500 \mathrm{~g}$ at $4{ }^{\circ} \mathrm{C}$. Then, the lower fraction which was $<10 \mathrm{kDa} \mathrm{MW}$ was collected. Then, the columns were turn over and centrifuged once more for $3 \mathrm{~min}$ at the same conditions to restore $>10 \mathrm{kDa}$ MW fraction of BCM-72 h.

\section{Mice}

Inbred CBA mice (8-12 weeks of age, 18-22 g) were maintained at the Animal Breeding Unit of the Department of Immunology of Jagiellonian University Medical College. All mice were held in standard caging conditions with water and standard diet ad libitum. This study was carried out in strict accordance with recommendations from the Guide for the Care and Use of Laboratory Animals of the Ministry of Science and Information of Poland. The protocol was approved by the I Local Committee on the Ethics of Animal Experiments of Jagiellonian University. All surgeries were performed under isoflurane 
(Abbott Laboratories) anesthesia. Every effort was made to minimize animal suffering. Mice were used as donors for peritoneal exudate cells.

\section{Cell isolation}

Peritoneal mouse exudate cells (PEC) were induced by an intraperitoneal injection of $1.5 \mathrm{ml}$ of $3 \%$ thioglycollate (Difco Laboratories). Mice were euthanized by overdosing with isoflurane vapors (Abbott Laboratories), followed by cervical dislocation. PEC were collected by washing out the peritoneal cavity with $5 \mathrm{ml}$ of PBS (Lonza) containing $5 \mathrm{U}$ heparin/ml (Polfa). Then, PEC were centrifuged, and red blood cells were lysed. Osmolarity was restored by addition of PBS. To obtain neutrophils, PEC were collected after $18 \mathrm{~h}$ or for macrophages $96 \mathrm{~h}$ after thioglycollate injections. For neutrophil collections, we have used 18 -h thioglycollateinduced peritoneal exudate cells. The cells were seeded to plastic plates and after $1 \mathrm{~h}$, we collected non-adherent cells (neutrophils) for further experiments. For peritoneal macrophage isolation, we have used the method described previously [30]. At least three mice were used as donors of PEC for each experiment.

\section{Cell culture and treatment}

Neutrophils and macrophages were cultured in 24-well flatbottom cell culture plates at $5 \times 10^{5} /$ well in IMDM medium (Lonza) supplemented with 5\% fetal bovine serum (FBS; Lonza), $2 \mathrm{mM}$ stable L-glutamine (Cytogen), and $50 \mathrm{mg} /$ $\mathrm{ml}$ gentamicin (KRKA) at $37{ }^{\circ} \mathrm{C}$ in an atmosphere of $5 \%$ $\mathrm{CO}_{2}$. To determine the influence of the biofilm forms of $P$. aeruginosa on innate immune cell activity, neutrophils and macrophages were stimulated with heat-killed whole bacterial cells (PAR5-72 h 20:1 and 100:1 bacteria per cell) or with 72-h conditioned media from bacterial cultures (BCM-72 h at 5-20\% total volume), if not otherwise stated. The effect was compared with that of bacterial cells (PAR5-8 h) and 8-h conditioned media (BCM-8 h). As a reference stimulus for N1/M1 neutrophils/macrophages, we used $100 \mathrm{ng} / \mathrm{ml}$ LPS from Escherichia coli strain 0111:B4 (LPS, Sigma-Aldrich). After $24 \mathrm{~h}$ of stimulation, culture supernatants were collected and frozen at $-80^{\circ} \mathrm{C}$ until use. Cells were used in a western blot analysis. In some experiments, neutrophils were cultured with BCM-72 h treated with inhibitors of DNA (BCM were incubated in the presence of $2.5 \mu \mathrm{l}$ of 1500 Kunitz DNAse I, Qiagen; chloroquine, Sigma-Aldrich $-2.5 \mu \mathrm{g} / \mathrm{ml}$ ) or/and with the inhibitor of LPS (polymyxin B, Sigma-Aldrich, $100 \mu \mathrm{g} / \mathrm{ml}$ ) or preincubated with EPS $(30 \mu \mathrm{g} / \mathrm{ml})$ for $1 \mathrm{~h}$ and then re-stimulated with LPS $(100 \mathrm{ng} / \mathrm{ml})$ or DNA $(3 \mu \mathrm{g} / \mathrm{ml})$.

\section{Cell viability}

Cell viability was monitored by mitochondrial-dependent reduction of MTT (Promega) to formazan and by means of LDH activity (lactate dehydrogenase) using LDH assay kit (Pierce) according to manufacturer's instruction. The viability of phagocytes was controlled in all experimental systems to avoid cytotoxic effect of the tested agents. The lowest viability of neutrophils was approximately $78 \%$ ( $24 \mathrm{~h}$ after exposition to DNA), in other groups, the viability of neutrophils was $\sim 80 \%$ and macrophages $\sim 90 \%$.

\section{Cytokine determination}

Cytokine levels in cell culture supernatants were measured by sandwich ELISA. Microtiter plates (Costar EIA/RIA plates, Corning Inc.) were coated with a cytokine-specific antibody. Expression levels of IL-6, IL-10, and IL-12p40 were measured according to the manufacturer's instructions (OptEIA Sets, BD Biosciences). TNF- $\alpha$ level was measured according to the manufacturer's instructions (ELISA ReadySet-Go, eBioscience). In all cases, $10 \%$ FBS in PBS was used as a blocking solution. TMB substrate solution (BioLegend) was used to develop a colorimetric reaction, which was stopped with $2 \mathrm{M}$ sulfuric acid. Optical density was measured at $450(570) \mathrm{nm}$ using a microtiter plate reader (PowerWaveX, Bio-Tek Instruments).

\section{Nitric oxide (NO) determination}

NO levels in culture supernatants of peritoneal thioglycollate-induced cells (neutrophils, macrophages) were quantified by the accumulation of nitrite as a stable end product, according to a modified Griess method [31]. Cell culture supernatant $(100 \mu \mathrm{l})$ was mixed with $14 \mathrm{mM}$ 4,4'-diaminodiphenylsulphone (Dapsone, Sigma-Aldrich) in $2 \mathrm{M} \mathrm{HCl}$ $(50 \mu \mathrm{l})$ and $0.1 \% \mathrm{~N}$-1-naphtylenediamine dihydrochloride $(50 \mu \mathrm{l})$ in deionized water. Absorbance of the tested culture supernatants at $550 \mathrm{~nm}$ was compared with a sodium nitrate standard $\left(\mathrm{NaNO}_{2}\right)$ curve.

\section{Prostaglandin $\mathrm{E}_{2}\left(\mathrm{PGE}_{2}\right)$ immunoassay}

$\mathrm{PGE}_{2}$ concentration in cell supernatants was determined by a $\mathrm{PGE}_{2}$ high-sensitivity ELISA kit (Enzo Life Sciences), according to the manufacturer's protocol.

\section{Western blot analysis}

$24 \mathrm{~h}$ after in vitro stimulation of macrophages or neutrophils, expression levels of COX-2, iNOS, and arginase-1 (Arg1) proteins in cell cytosol were determined by western blot analysis. After incubation, cells were lysed in lysis buffer 

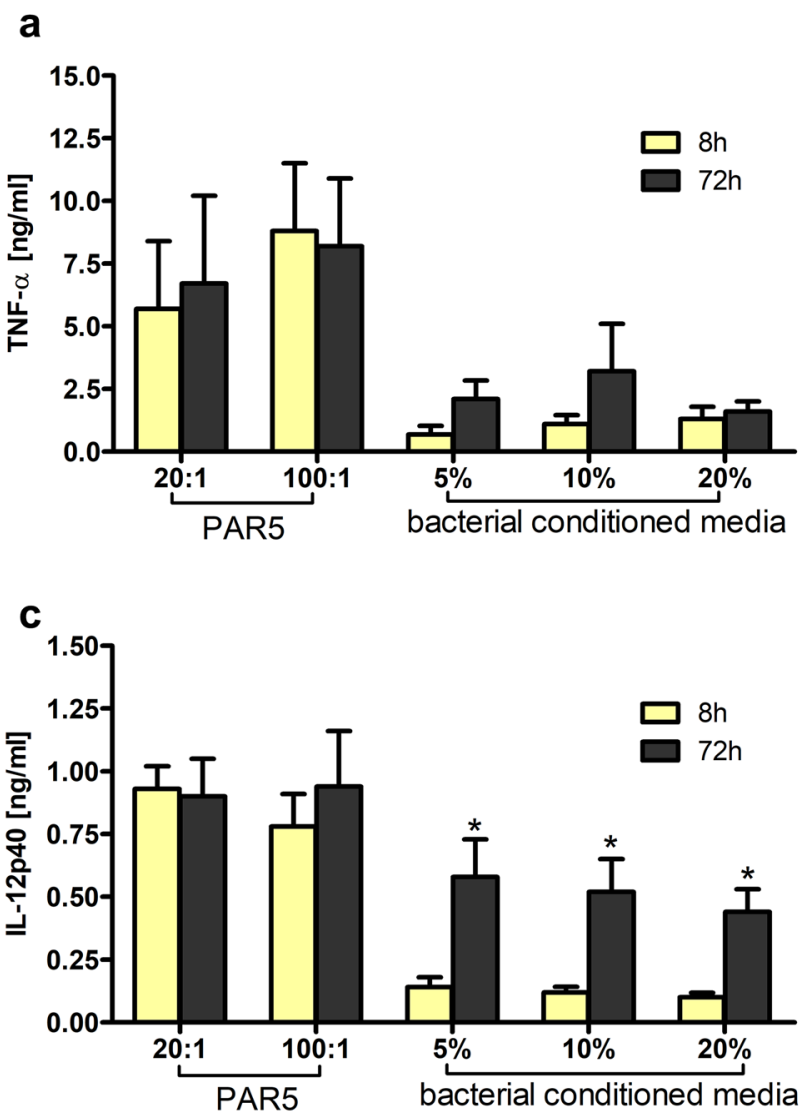

Fig. 2 Cytokine production by neutrophils exposed to heat-killed bacteria cells (PAR5) or bacterial-conditioned media (BCM). Levels of TNF- $\alpha$ (a), IL-6 (b), IL-12p40 (c), and IL-10 (d) were analyzed by ELISA of supernatants collected from 24-h cultures of neutrophils $\left(5 \times 10^{5} /\right.$ well). Neutrophils were activated with tested bacteria at $20: 1$ and 100:1 ratios of PAR5:neutrophils or with bacterial-conditioned media $(5,10,20 \%$ of total volume). Yellow bars: PAR5-8 $\mathrm{h}$ and

(1\% Triton X-100, 0.1\% SDS in PBS) containing protease inhibitor cocktail (Sigma-Aldrich). Protein concentrations in lysates were determined using a bicinchoninic acid protein assay kit (Sigma-Aldrich). Samples containing equal amounts of total protein were mixed with gel loading buffer (0.125 M Tris, 4\% SDS, 20\% glycerol, 0.2 M dithiothreitol, $0.02 \%$ bromophenol blue) in a $2: 1$ ratio $(\mathrm{v} / \mathrm{v})$ and boiled for $4 \mathrm{~min}$. Samples of $20 \mu \mathrm{g}$ of total protein per lane were separated on $10 \%$ SDS-polyacrylamide gels (Mighty Small II, Amersham Biosciences) using the Laemmli buffer system. Proteins were transferred to nitrocellulose membranes (Bio-Rad). Non-specific binding sites were blocked overnight at $4{ }^{\circ} \mathrm{C}$ with $3 \%$ non-fat dried milk. Membranes were incubated for $2 \mathrm{~h}$ at RT with rabbit polyclonal antibodies to COX-2 (cat. no. 160106, 1:1000, Cayman), Arg-1 (clone H-52, 1:600, Santa Cruz Biotechnology), or iNOS (ADIKAS-NO001, 1:2000, Enzo Life Sciences). Bands were detected with alkaline phosphatase-conjugated secondary goat antibody to the rabbit IgG whole molecule (A9919, $1 \mathrm{~h}$ b
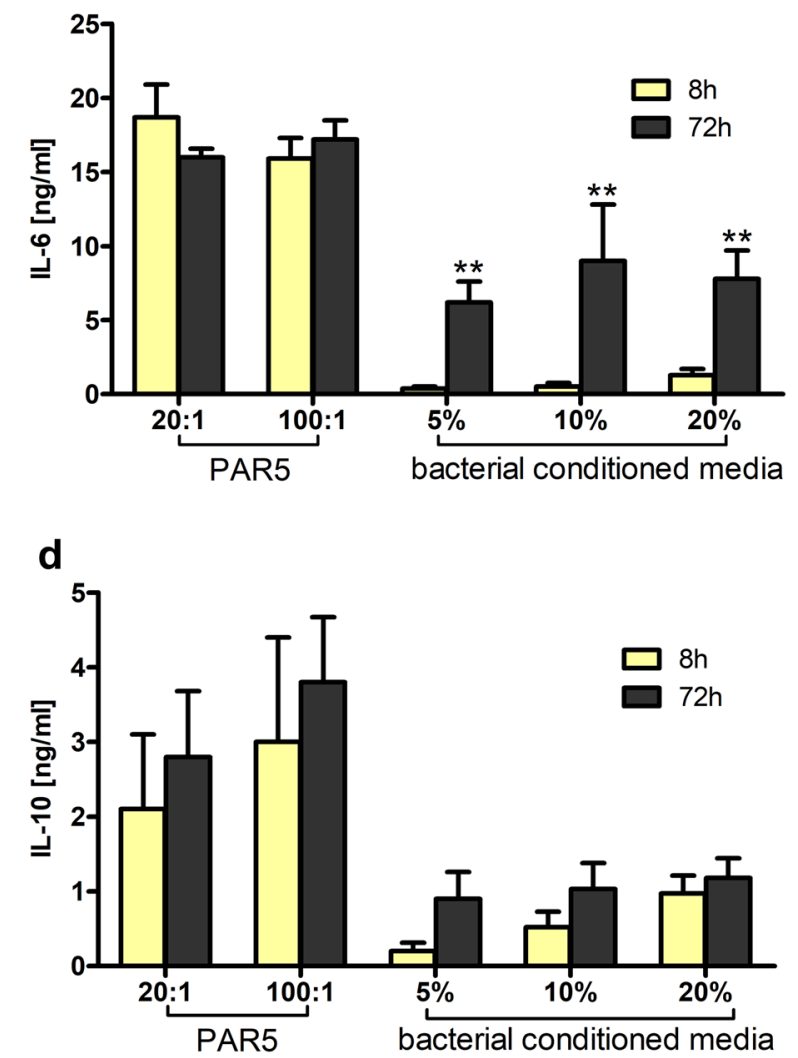

BCM-8 h. Black bars: PAR5-72 h and BCM-72 h. Cytokine levels in non-stimulated cells were: TNF- $\alpha$ and IL- 6 below the detection limit, for IL-10 and IL-12p40, $<0.075$ and $<0.035 \mathrm{ng} / \mathrm{ml}$, respectively. Data are mean \pm SEM values of three independent experiments. Each group was run in triplicates. ${ }^{*} p<0.05, * * p<0.005$ at $8 \mathrm{~h}$ vs. $72 \mathrm{~h}$, Student's $t$ test. (Color figure online)

at RT, 1:3000, Sigma-Aldrich) and developed with BCIP/ NBT alkaline phosphatase substrate (Sigma-Aldrich). Membranes were re-probed with monoclonal mouse anti $\beta$-actin antibody (clone AC-15, $1 \mathrm{~h}$ at RT, 1:3000, Sigma-Aldrich). Pre-stained SDS-PAGE standards (low and high range; BioRad) were used for molecular weight (MW) determinations. Protein bands were scanned and analyzed with the Scion Image freeware (Scion Corp.). Data were normalized to the constitutive expression level of $\beta$-actin protein.

\section{Data analysis}

Statistical significance of differences between groups was analyzed using one-way ANOVA, followed, if significant, by a Dunnett's test for post hoc comparison. In some experiments, Student's $t$ test was used. Results are expressed as mean \pm SEM values. A $P$ value $<0.05$ was considered statistically significant. Analysis was performed using Graphpad 

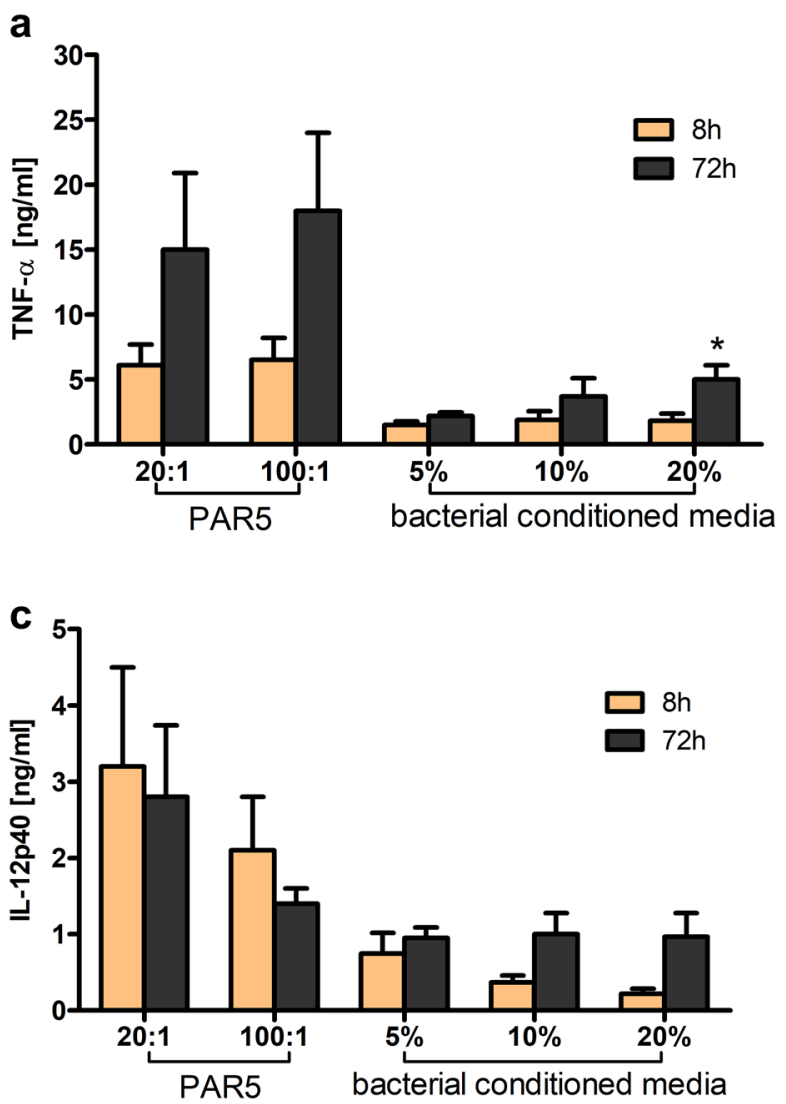

Fig. 3 Cytokine production by macrophages exposed to heat-killed bacteria cells (PAR5) and bacterial-conditioned media (BCM). Levels of TNF- $\alpha$ (a), IL-6 (b), IL-12p40 (c), and IL-10 (d) were analyzed by ELISA of supernatants collected from 24-h cultures of macrophages $\left(5 \times 10^{5} /\right.$ well $)$. Macrophages were activated with tested bacteria used at 20:1 and 100:1 ratios of PAR5:macrophages or with bacterial-conditioned media $(5,10,20 \%$ of total volume). Orange bars:

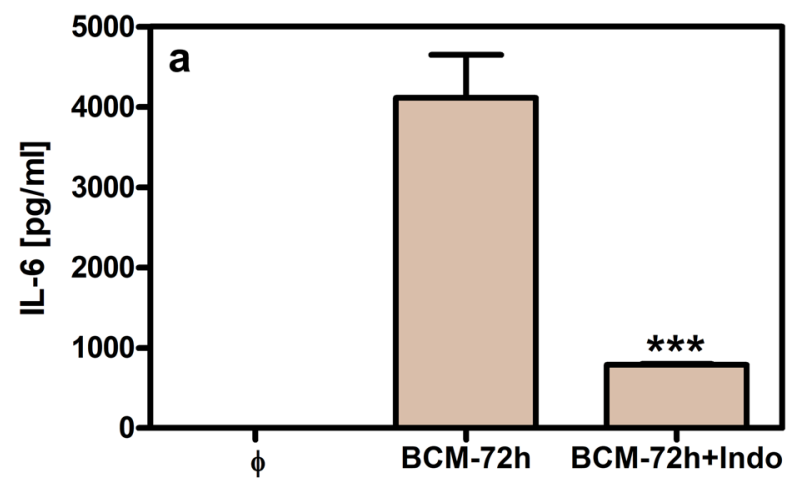

Fig. 4 Influence of indomethacin (Indo) on IL-6 secretion by neutrophils and macrophages stimulated with BCM-72 h. Neutrophils (a) and macrophages $(\mathbf{b})$ at $5 \times 10^{5} /$ well were stimulated with BCM-72 $\mathrm{h}$ $(20 \%)$ in the presence or absence of Indo $(10 \mu \mathrm{M})$. IL-6 level was analyzed in supernatants collected from 24-h cell cultures by ELISA. b

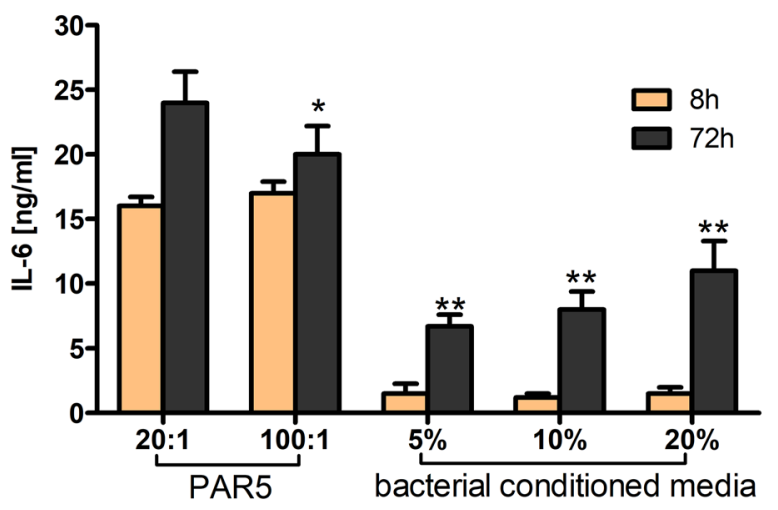

d

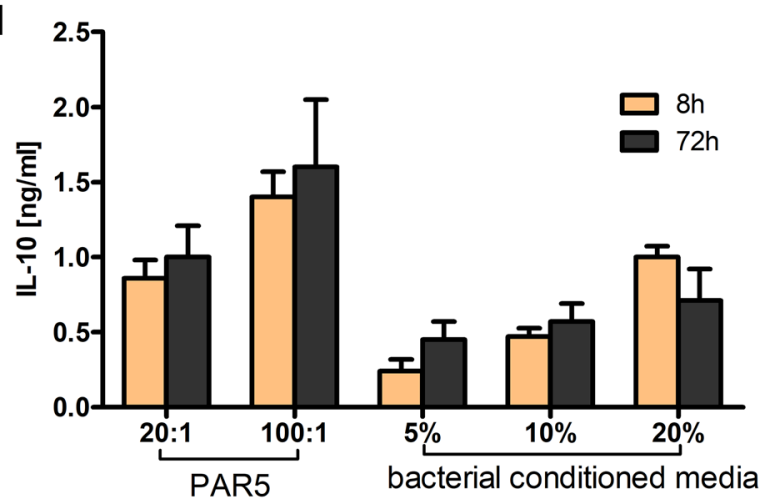

PAR5- $8 \mathrm{~h}$ and BCM- $8 \mathrm{~h}$. Black bars: PAR5-72 $\mathrm{h}$ and BCM-72 $\mathrm{h}$. Cytokine levels in non-stimulated cells were: TNF- $\alpha<0.036 \mathrm{ng} / \mathrm{ml}$, IL- 6 below the detection limit, for IL- $10<0.010 \mathrm{ng} / \mathrm{ml}$ and IL-12p40, $<0.180 \mathrm{ng} / \mathrm{ml}$. Data are mean \pm SEM values of three independent experiments. Each group was run in triplicates. $* p<0.05$, $* * p<0.005$ for $8 \mathrm{~h}$ vs. $72 \mathrm{~h}$, Student's $t$ test. (Color figure online)

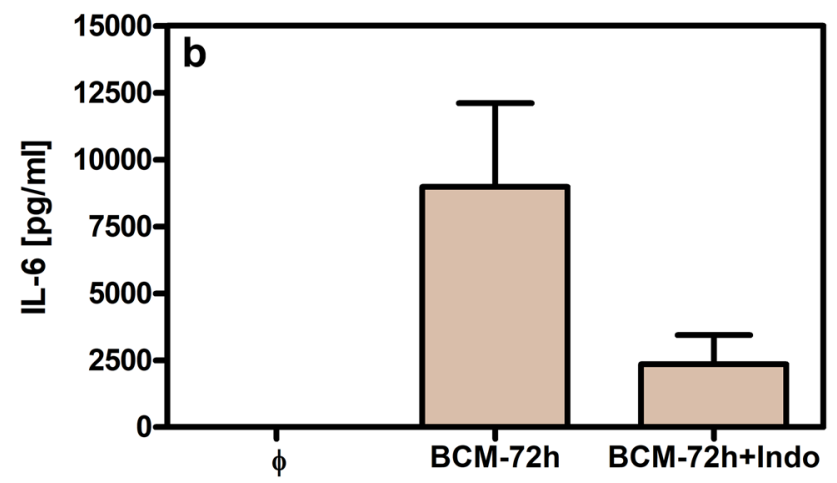

$\varphi$-non-stimulated cells, expressed IL-6 release below $0.1 \mathrm{ng} / \mathrm{ml}$. Data are mean \pm SEM values of three independent experiments. Groups were run in triplicates. $* * * p<0.001$ for BCM-72 h vs. BCM72 h + Indo, one-way ANOVA 

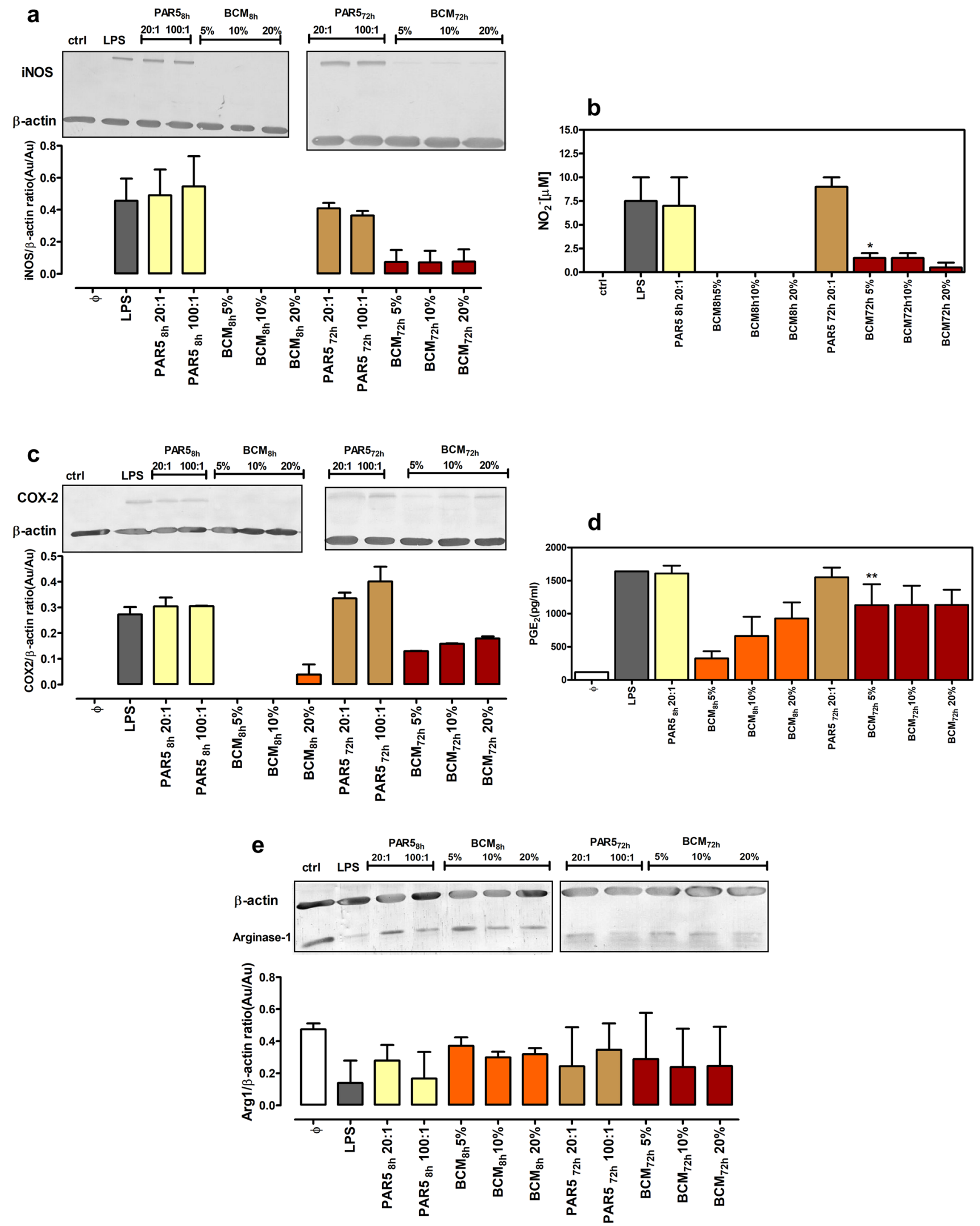
4Fig. 5 Expression of iNOS, COX-2, and Arg-1 proteins in neutrophils exposed to PAR5 or bacterial-conditioned media. Expression levels of iNOS (a), COX-2 (c), and Arg-1 (e) were measured by western blot analysis of cell lysates collected from 24-h cultures of neutrophils $\left(5 \times 10^{5} /\right.$ well $)$. Neutrophils were activated with tested bacteria at a ratio of 20:1 and 100:1 of PAR5:neutrophils, with bacterialconditioned media (the $\%$ of total volume) or with LPS $(0.1 \mu \mathrm{g} / \mathrm{ml})$ as a control. Densitometric analysis of bands from two experiments is shown. Data are normalized to constitutive expression levels of $\beta$-actin. In the same experiments, levels of $\mathrm{NO}_{2}(\mathbf{b})$ and $\mathrm{PGE}_{2}(\mathbf{d})$ in supernatants were measured. * $p<0.05$, ** $p<0.005$ for $5 \%$ BCM- $8 \mathrm{~h}$ vs. $5 \% \mathrm{BCN}-72 \mathrm{~h}$, one-way ANOVA

Prism v. 5.01 (GraphPad Software, Inc.). The exact statistical analysis is named in the relevant figure's capitation.

\section{Results}

\section{Cytokine production by cells exposed to $P$. aeruginosa PAR5}

Pseudomonas aeruginosa switches from a planktonic to a biofilm-producing stage during prolonged culture in vitro. We exposed neutrophils and macrophages to killed bacteria cells (PAR5) or bacterial-conditioned media isolated from bacterial cultures after $8 \mathrm{~h}$ beginning of biofilm formation-planktonic stage of bacteria growth—see SEM images (Fig. 1) or $72 \mathrm{~h}$ (biofilm matrix formation-mature biofilm).

As shown in Fig. 2, neutrophils stimulated with PAR5$72 \mathrm{~h}$ bacterial cells produced similar amounts of all tested cytokines (TNF- $\alpha$, IL-6, IL-12p40, and IL-10) as those stimulated with PAR5-8 $\mathrm{h}$ bacteria. Macrophages, cultured under the same conditions, showed a trend towards higher production of TNF- $\alpha$ and IL-10, and a significantly higher production of IL-6 when stimulated with biofilm PAR5-72 $\mathrm{h}$ bacterial cells (Fig. 3). The ratio of bacteria to activated target cells (MOI-multiplicity of infection of 100:1 vs. 20:1 bacteria per cell) had no substantial impact on the cytokine profile or total production.

On the other hand, comparison of bacterial supernatants, rather than cells, showed a different pattern. Neutrophils stimulated with BCM-72 $\mathrm{h}$ released significantly more IL-6 and IL-12p40 than those stimulated with BCM-8 h (Fig. 2). The level of IL-6 in neutrophil cultures exposed to BCM$72 \mathrm{~h}$ was more than tenfold higher than the level of IL-6 stimulated with BCM-8 $\mathrm{h}$ (Fig. 2b). The stimulation of macrophages with BCM-72 $\mathrm{h}$ showed a massive release of IL-6, and a trend towards increased IL-12p40 production (Fig. 3).

Importantly, the IL-6:IL-10 ratio reached 15:1 for macrophages and 7:1 for neutrophils, suggesting a strong proinflammatory state of activation. An enhanced TNF- $\alpha$ :IL-10 ratio in supernatants collected from the cells exposed to BCM-72 h (3:1 for neutrophils, 6:1 for macrophages) confirms the proinflammatory profile of these cells.
Moreover, the inhibition of prostaglandins production with indomethacin significantly reduced the production of IL-6, suggesting a positive proinflammatory feedback between these two mediators may operate (Fig. 4a, b).

\section{iNOS, Arg-1, and COX-2 expression in cells exposed to $P$. aeruginosa PAR5}

In parallel to determining cytokine secretion, we measured expression levels of iNOS, COX-2 and Arg-1. iNOS and COX-2 are proinflammatory enzymes responsible for productions of $\mathrm{NO}$ and $\mathrm{PGE}_{2}$, respectively, whereas Arg- 1 is a key marker of immunoregulatory $\mathrm{N} 2$ neutrophils and M2 macrophages [22, 32].

Stimulation of neutrophils and macrophages with PAR5-8 $\mathrm{h}$ and PAR5-72 bacteria caused a massive induction of iNOS and COX-2 proteins in these cells, together with significant secretion of nitrites (stable NO metabolites) and $\mathrm{PGE}_{2}(>1.5 \mathrm{ng} / \mathrm{ml})$. There were no differences in Arg-1 expression in cells stimulated with PAR5-8 $\mathrm{h}$ and PAR5-72 $\mathrm{h}$ (Figs. 5, 6).

Soluble products of $P$. aeruginosa (BCM) produced at early and late phases of culture differentially affected the expression levels of tested enzymes. BCM- $8 \mathrm{~h}$ did not induce the expression of iNOS or COX-2 in inflammatory cells and the expression of Arg-1 was similar to that of control nonstimulated cells (Figs. 5, 6). In contrast, BCM-72 h induced iNOS and COX-2 expression, similar to stimulation with LPS, the prototypical stimulus for proinflammatory N1/M1 cells. However, neutrophils and macrophages stimulated with BCM-72 h produced substantial amounts of inflammatory $\mathrm{PGE}_{2}$ (Figs. 5d, 6d) while the production of microbicidal NO was negligible (Figs. 5b, 6b). All these results point to hyperinflammatory state of activation of the cells exposed to BCM-72 $\mathrm{h}$.

\section{Effect of LPS and DNA inhibitors on stimulatory properties of BCM-72 $h$}

While BCM-72 h showed a similar capacity to induce the production of proinflammatory mediators as whole bacterial cells of PAR5, BCM-8 h showed only weak stimulatory properties. These observations suggest that BCM- $8 \mathrm{~h}$ contains low subactive concentrations of active extracellular bacterial biofilm products, consistent with previously reported growth rate of biofilm by $P$. aeruginosa $[11,23$, 33, 34]. As shown in Fig. 1b, a substantial amount of EPS produced by PAR5 was observed after $24 \mathrm{~h}$ of biofilm formation, followed by a plateau (48-72 h) and a breakdown of biofilm mass after $72 \mathrm{~h}$ of culture. In contrast, after $8 \mathrm{~h}$, the EPS amount was negligible and cells could be considered as planktonic cells not hidden in a biofilm matrix. Moreover, BCM-8 h contained several times lower concentrations of 
LPS and DNA than BCM-72 h (Fig. 1b). This might explain weak stimulatory activity of BCM- $8 \mathrm{~h}$.

We, therefore, examined the contribution of different components of BCM-72 $\mathrm{h}$ to the activation of phagocytes in more detail. For this purpose, we focused on neutrophils, the major infiltrating cells in severe $P$. aeruginosa infections. First, we excluded the contribution of small molecules, such as QS molecules, in the biological activity of BCM-72 $\mathrm{h}$. Fractions of BCM-72 h with MW below $10 \mathrm{kDa}$ were not able to stimulate phagocytes for the production of cytokines. By contrast, the fractions with MW above $10 \mathrm{kDa}$ showed the same stimulatory capacity as intact BCM-72 $\mathrm{h}$ (data not shown). Therefore, bacterial components of high MW, such as extracellular DNA, LPS and EPS, were the major candidates to be held responsible for the proinflammatory properties of BCM-72 h.

Addition of DNase I and chloroquine (an endosomal acidification blocker and selective inhibitor of the DNA/ TLR9 pathway) [35], or polymyxin $b$ (PMx, an inhibitor of LPS [36]) markedly blocked the ability of BCM to stimulate cytokine production by neutrophils (Fig. 7a-c). Importantly, the mixture of LPS and DNA inhibitors decreased both TNF- $\alpha$ and IL- 6 production by more than $95 \%$. This indicates that EPS did not contribute to BCM-72 h activity and suggests that EPS present in 20\% BCM-72 $\mathrm{h}$ was at nonstimulatory concentrations.

\section{Stimulatory properties of purified LPS, DNA and EPS isolated from $\mathrm{BCM}-72 \mathrm{~h}$}

To support the above observations, neutrophils were exposed to pure LPS, DNA and EPS isolated from BCM-72 h. First, we have estimated the lowest effective concentrations of the agents. All tested agents markedly stimulated IL-6 secretion from neutrophils at concentrations above $100 \mathrm{ng} / \mathrm{ml}$ for LPS, $3 \mu \mathrm{g} / \mathrm{ml}$ for DNA and $30 \mu \mathrm{g} / \mathrm{ml}$ for EPS (data not shown).

Then, the activity of the agents, used at the above concentrations, was compared with the activity of E. coli LPS $(100 \mathrm{ng} / \mathrm{ml})$, referential stimulator of inflammatory mediators. As shown in Fig. 8, neutrophils exposed to DNA secreted significantly more tested cytokines than those stimulated with $E$. coli LPS. Importantly, the effect was observed at the concentration of DNA similar to that observed in BCM-72 $\mathrm{h}$ used in our experimental models (10\% BCM-72 h).

By contrast, PAR5 LPS was weaker stimulator of neutrophil cytokine production than E. coli LPS. However, it favors the production of proinflammatory cytokines (TNF- $\alpha$ :IL-10 ratio was 50:1 for PAR5 LPS and 10:1 for E.coli LPS).

EPS showed stimulatory properties similar to DNA but at the concentration much higher than that estimated in BCM $72 \mathrm{~h}-20 \%$. Importantly, joint effect of the agents on the production of proinflammatory cytokines (TNF- $\alpha$, IL-6) was similar to that achieved by stimulation with DNA alone. Moreover, preincubation of neutrophils with EPS, the primarily macromolecule of biofilm matrix, did not alter the neutrophil capacity to secrete inflammatory mediators after LPS and DNA stimulation (Fig. 8).

\section{Discussion}

Biofilm formation in the course of $P$. aeruginosa infections is associated with the development of chronic inflammation and pathogen persistence [5]. In this study, we demonstrate that biofilm is a rich source of concentrated extracellular phagocyte-activating bacterial components, including DNA, LPS and EPS. Importantly, our knowledge of bacteria-neutrophil interactions has evolved since discoveries of the different immunostimulatory properties of planktonic and biofilm forms of pathogens [8, 37]. Bacterial infections start with planktonic growth followed by a formation of biofilm. More importantly, interactions of bacteria with neutrophils at planktonic stage of infections usually result in pathogen killing, controlled production of inflammatory mediators, neutrophil apoptosis and the resolution of acute inflammation. On the contrary, the biofilm stage of bacterial infection favors necrosis of neutrophils and causes chronic inflammation $[8,21]$.

Chronic $P$. aeruginosa infection is the outcome of a complex series of changes in $P$. aeruginosa phenotype. Infection with "wild-type" strains of $P$. aeruginosa is characterized by the proliferation of planktonic form of bacteria cells. Their long persistence is associated with complex mechanisms of adaptation and shift from planktonic to biofilm phenotypes. Moreover, biofilm-type pathogens undergo genetic, phenotypic and physiological diversification [38]. These biofilmforming strains colonize infected tissue and exist at various stages of biofilm development in numberless macrocolonies [39]. Such biofilm lifestyle cycle lasts 4-10 days and can be subdivided into following steps: attachment or aggregation of bacterial planktonic cells, formation of biofilm matrix, biofilm maturation, cell detachment and dispersion. Finally, such free-living biofilm cells, misleadingly termed as planktonic cells, spread and colonize host tissues to form biofilms at new sites [40]. Herein, in this study, all experiments were performed using the selected mucoid bacterial strain of $P$. aeruginosa showing a massive production of biofilm components.

The main objective of this study was to show that neutrophils and macrophages can be effectively stimulated by $P$. aeruginosa-derived biofilm extracellular substances without direct contact with bacterial cells, because the biofilm provides a very concentrated stable source of PAMPS which are otherwise present at very low concentrations in bacterial culture supernatant. We further hypothesize that the presence 

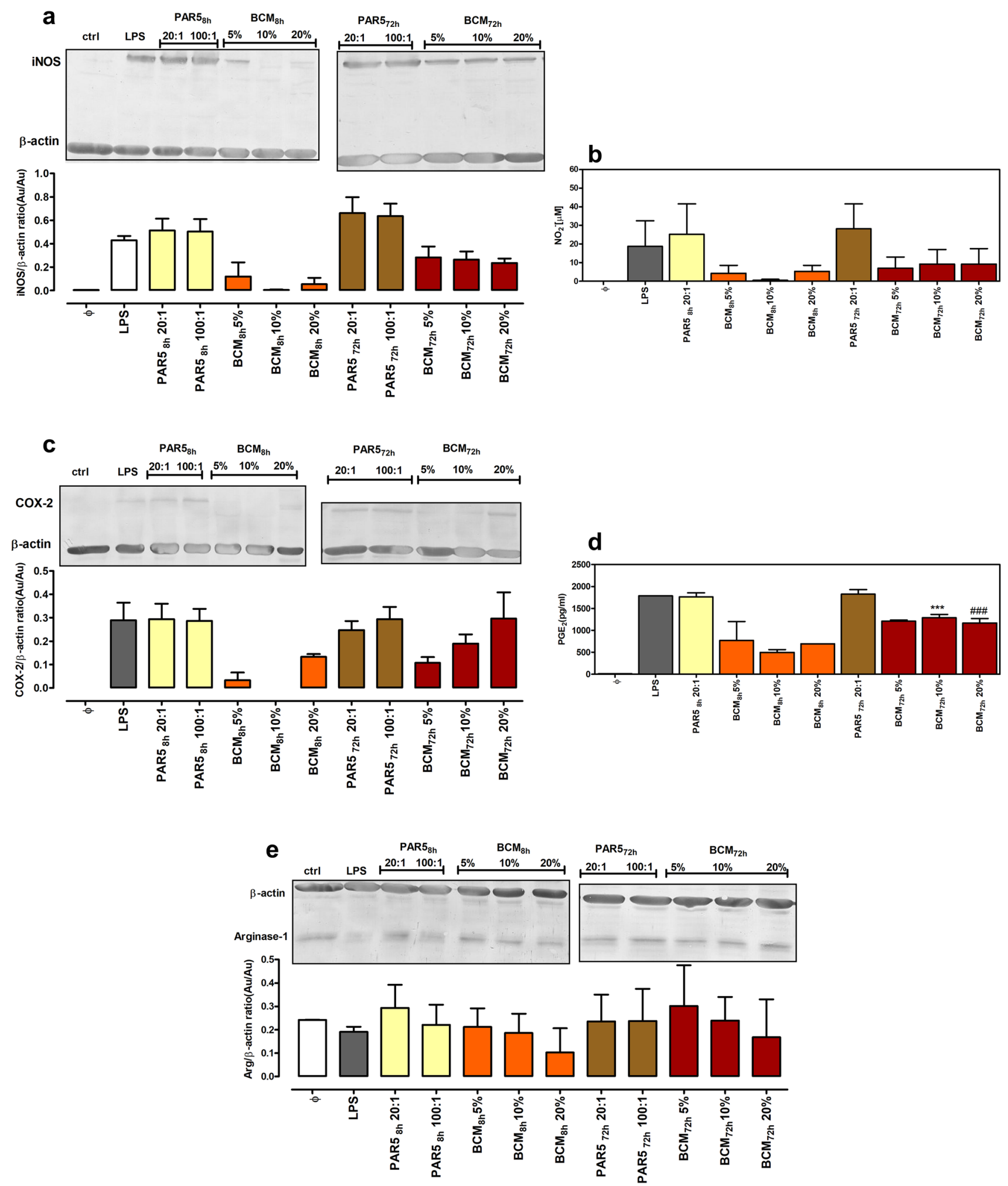

Fig. 6 Expression of iNOS, COX-2 and Arg-1 proteins in macrophages exposed to PAR5 or bacterial-conditioned media. Expression levels of iNOS (a), COX-2 (c), and Arg-1 (e) were measured by western blot analysis of cell lysates collected from 24-h cultures of macrophages $\left(5 \times 10^{5} /\right.$ well $)$. Macrophages were activated with tested bacteria at a ratio of 20:1 and 100:1 of PAR5:macrophages, with bacterial-conditioned media (the $\%$ of total volume) or with LPS $(0.1 \mu \mathrm{g} /$ $\mathrm{ml}$ ) as a control. Densitometric analysis of bands from two experiments is shown. Data are normalized to constitutively expressed $\beta$-actin levels. In the same experiments, levels of $\mathrm{NO}_{2}(\mathbf{b})$ and $\mathrm{PGE}_{2}$ (d) in supernatants were measured. $* * * p<0.001$ for $10 \%$ BCM- $8 \mathrm{~h}$ vs. $10 \%$ BCM-72 h, \#\#\# $p<0.001$ for $20 \%$ BCM- 8 h vs. $20 \%$ BCM72 h, one-way ANOVA 

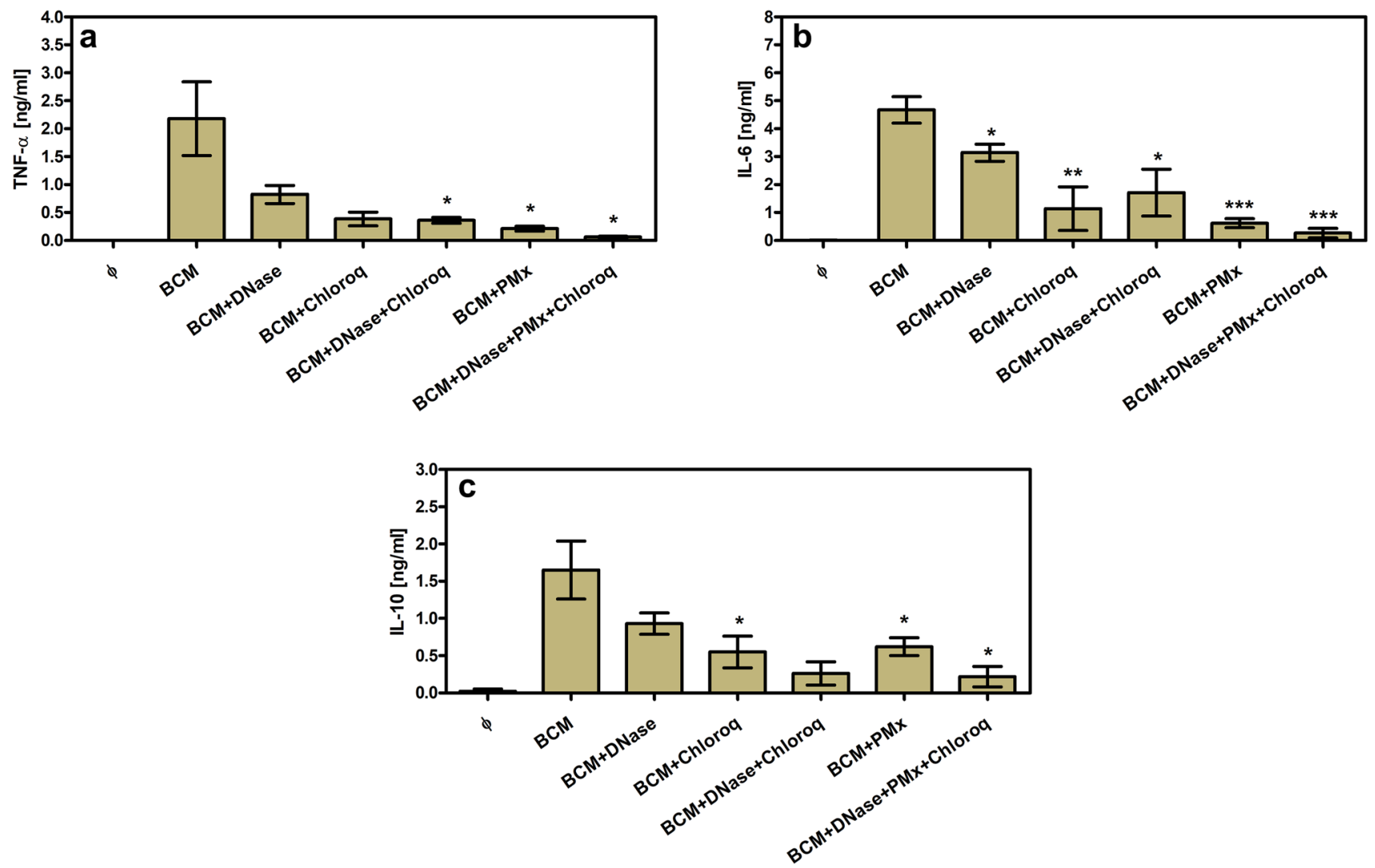

Fig. 7 Effect of LPS and DNA inhibitors on stimulatory properties of BCM-72 h. Neutrophils at $5 \times 10^{5} /$ well were cultured with $20 \%$ BCM72 h: (i) untreated, (ii) treated with DNA inhibitors (DNase and/or chloroquine), (iii) treated with inhibitor of LPS (PMx), (iv) treated with all tested inhibitors. TNF- $\alpha$ (a), IL-6 (b) and IL-10 (c) levels

of such stimulated cells (BANs, BAMs) in a hyperinflammatory state of activation may explain the detrimental role of neutrophils in chronic $P$. aeruginosa infection associated with the pathogenesis of CF [41, 42] and, as we have previously observed, in chronic rhinosinusitis [15].

We explored the role of the biofilm using, as a model, conditioned medium from a high biofilm producer strain of $P$. aeruginosa, and as responding innate immune cells murine macrophages and neutrophils. As we expected, $72 \mathrm{~h}$, but not 8-h cultures of $P$ aeruginosa PAR5 were a rich source of biofilm components, including DNA, LPS and EPS. Importantly, the density of PAR5 in our experimental model of bacterial cultures $\left(10^{7}-5 \times 10^{9} \mathrm{CFU} / \mathrm{ml}\right)$ was similar to $P$. aeruginosa sputum densities demonstrated in cystic fibrosis patients [43]. The density of infiltrated neutrophils in CF sputum [44] is 10-20 times higher than the density of in vitro-stimulated leukocytes $\left(5 \times 10^{5} / \mathrm{ml}\right)$. Therefore, one may expect even stronger hyperinflammatory response in vivo. were analyzed by ELISA in supernatants collected from 24-h cell cultures. Data are mean \pm SEM values of three independent experiments. Each group was run in triplicates. ${ }^{*} p<0.05$, $* * p<0.005$, $* * * p<0.001$ between treated and untreated BCM-72 h, one-way ANOVA

Conditioned medium from early cultures of PAR5, which contained small amounts of biofilm products, showed a weak stimulation of either neutrophils or macrophages. The lack of biofilm components at this time point is in agreement with the previously observed growth rate of $P$. aeruginosa biofilms and scant release of EPSs at this stage of biofilm development [23, 45].

However, when the PAR5 culture was extended to $72 \mathrm{~h}$, biofilm production could easily be detected. In parallel, the conditioned medium (BCM-72 h) acquired strong stimulatory properties towards both neutrophils and macrophages. Specifically, the conditioned medium induced the release

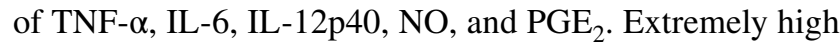
release of IL-6 was observed from targeted cell types, resulting in a high ratio of IL-6/IL-10, well-known pro- and antiinflammatory cytokines. To confirm a causal link between the increased concentrations of DNA and LPS associated with biofilm formation, and the immunostimulatory properties of the conditioned medium we removed DNA using DNAse enzyme, and blocked LPS activity using polymyxin 

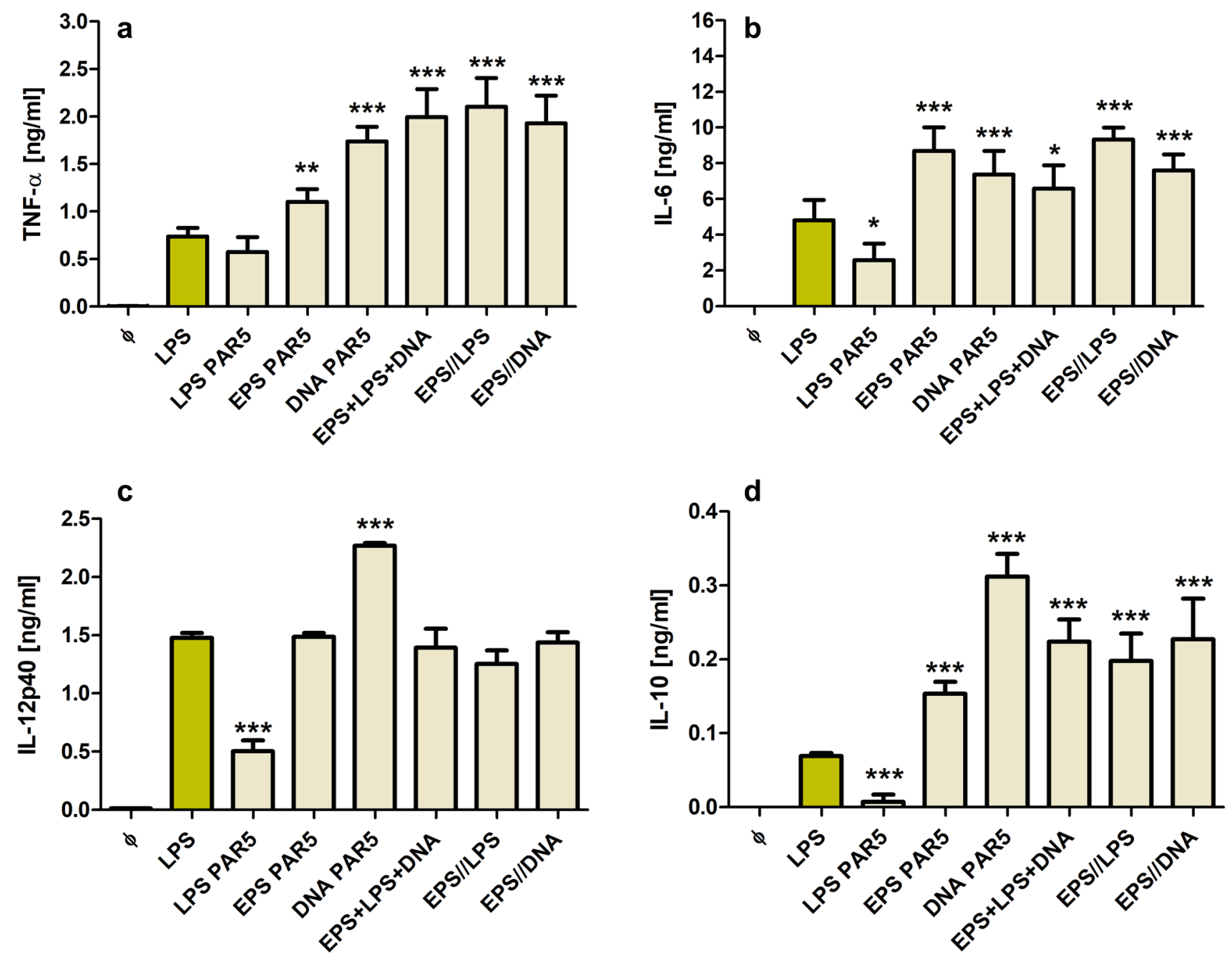

Fig. 8 Cytokine production by neutrophils exposed to agents isolated from BCM-72 h. Levels of TNF- $\alpha$ (a), IL-6 (b), IL-12p40 (c), and IL-10 (d) were analyzed by ELISA of supernatants collected from 24 -h cultures of neutrophils $\left(5 \times 10^{5} /\right.$ well $)$. Neutrophils were stimulated with tested agents isolated from PAR5 BCM at concentrations: LPS $-100 \mathrm{ng} / \mathrm{ml}$, EPS $-30 \mu \mathrm{g} / \mathrm{ml}$ and DNA $-3 \mu \mathrm{g} / \mathrm{ml}$. In two last groups, the cells were preincubated for $1 \mathrm{~h}$ with EPS and then re-

B. Both these components strongly contributed to the proinflammatory activity of the conditioned medium, as their inhibition almost completely abolished the activity of BCM$72 \mathrm{~h}$. On the other hand, the incubation of neutrophils with pure DNA and LPS isolated from BCM-72 $\mathrm{h}$ showed that both agents, at concentrations close to those at $20 \%$ BCM$72 \mathrm{~h}$, markedly stimulated proinflammatory mediators.

Our results are in agreement with previous studies reported that components of biofilm matrix exert proinflammatory properties associated with the pathogenicity of biofilm-forming $P$. aeruginosa. These components primarily include QS molecules [9, 46], EPSs [10, 34], and finally, LPS and extracellular bacterial DNA, two major virulence and proinflammatory factors of $P$. aeruginosa biofilms [13,

stimulated with LPS or DNA. After $24 \mathrm{~h}$, supernatants were collected and the amounts of cytokines were estimated. Data are mean \pm SEM values of three independent experiments. Each group was run in triplicates. As a control, LPS from E. coli was used (LPS, $100 \mathrm{ng} /$ $\mathrm{ml}) .{ }^{*} p<0.05,{ }^{* *} p<0.005,{ }^{* *} p<0.001$ vs. LPS E.coli, one-way ANOVA

33, 47, 48]. We excluded the effect of QS molecules from our experiments because there was no BCM-72 $\mathrm{h}$ activity in the low MW fraction $(<10 \mathrm{kD})$. In addition, a combined neutralization of DNA and LPS completely blocked BCM$72 \mathrm{~h}$ activity. Such blockade excluded the significant contribution of other agents including EPS. Why EPS, the major component of $P$. aeruginosa biofilm, was not active? One possibility is that EPSs have a non-effective concentration in BCM-72 $\mathrm{h}$. Indeed, we have shown that EPSs isolated from PAR5 BCM-72 h stimulate cytokine production by neutrophils at high concentrations $(>30 \mu \mathrm{g} / \mathrm{ml})$ which were not achieved in the tested bacterial-conditioned media $(<20 \%$ BCM-72 h). Nevertheless, P. aeruginosa-derived EPS (e.g., alginate) may achieve very high concentrations in vivo at 


\section{Planktonic form of PAR $\longrightarrow \Delta$ Biofilm form of PAR}

LPS activates TLR4

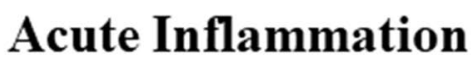

EPS, bDNA, LPS, QS trapped in biofilm Hyperinflammation

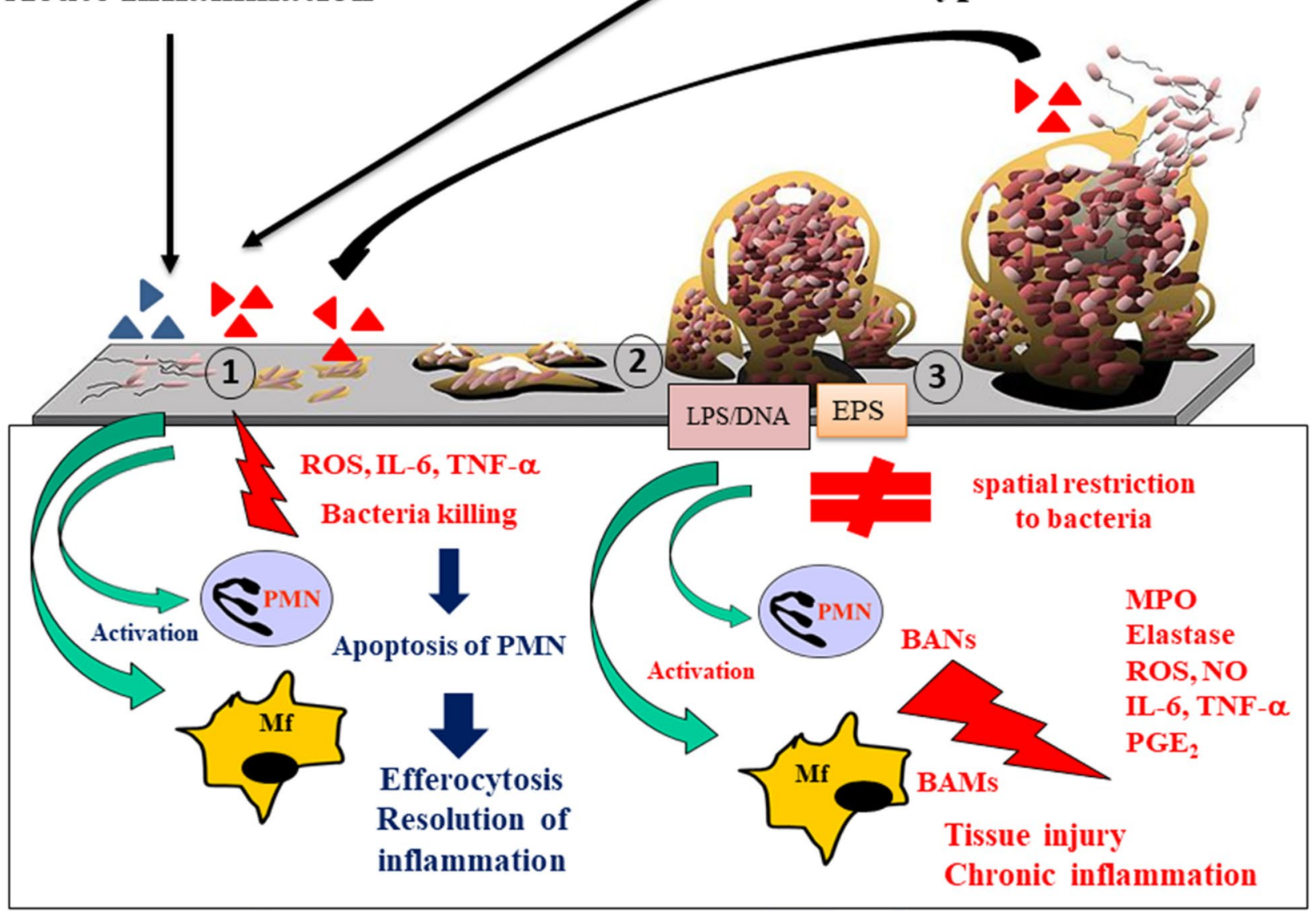

Fig. 9 Proposed model for cross talk between P. aeruginosa (PAR) and innate immunity (neutrophils and macrophages) at a site of acute and chronic inflammation. Acute infection and acute inflammation: at an early stage of infection planktonic form of $P$. aeruginosa induces an inflammatory response through TLRs at the site of bacteria entry. Activation of infiltrating neutrophils results in the production of inflammatory mediators and stimulation of phagocytosis, which kills planktonic bacterial cells. After eliminating pathogens, neutrophils die by apoptosis and are silently phagocytosed (neutrophil efferocytosis) by macrophages. Finally, acute infection and inflammation are terminated. However, if pathogens are not killed they will attach to host cells, build a biofilm and chronic infection will develop. Chronic infection and chronic inflammation: bacteria that acquired biofilmtype properties can survive as sessile cells in a few days long biofilm cycle (biofilm development stages: (1) irreversible attachment of bacteria to infected host cells or aggregation in body fluids, (2) bio- film formation and maturation, (3) bacteria cell dispersion, colonization of other sites, building one to three new biofilms). Formation of a biofilm matrix is accompanied by the local accumulation of EPSs, DNA, and LPS molecules reaching immunostimulatory concentrations. In the course of biofilm maturation, extracellular LPS and DNA seem to be major stimulators of neutrophils (BANs) and macrophages (BAMs), while EPS acts as a physical barrier and as a trap for other biofilm matrix components. The interaction between biofilm and BANs/BAMs might, therefore, favor hyperinflammation associated with tissue injury rather than effective killing of pathogens and resolution of acute inflammation. Such scenario is in agreement with clinical reports showing massive neutrophil infiltration in chronic $P$. aeruginosa infections with concomitant release of detrimental substances such as elastase, ROS, NO, prostaglandins and proinflammatory cytokines chronic inflammation sites [49]. Therefore, in vivo, EPS not only protects bacteria hidden in a biofilm matrix against the immune attack, but also traps extracellular LPS and DNA to maintain their long-term effective immunostimulatory concentrations. Importantly, DNA and LPS, in contrast to EPS, can effectively activate inflammatory cells at very low concentrations $(<1 \mu \mathrm{g} / \mathrm{ml})$ [48]. Indeed, in our experimental conditions, DNA and LPS, the major components of BCM$72 \mathrm{~h}$, independently stimulated the massive cytokine production in neutrophils. These findings are consistent with previous observations that extracellular DNA, apart from its role in biofilm composition, is an extremely active component 
of $P$. aeruginosa biofilms. Extracellular DNA triggers neutrophil activation through TLR9-dependent/-independent mechanisms, causes target cell death by necrosis and exacerbates chronic $P$. aeruginosa infections [12, 35, 48]. Moreover, it has been reported that DNA can initiate lung injury by stimulating neutrophil-endothelial cell interactions predisposing to the increase in endothelial permeability [35].

Interestingly, the massive production of IL-6 and $\mathrm{PGE}_{2}$ is in response to PAR5 stimulation. This observation confirms a role of the $\mathrm{PGE}_{2} / \mathrm{IL}-6$ axis in $P$. aeruginosa pathogenicity. Indeed, IL-6 levels have been reported to be increased markedly in cystic fibrosis patients when the disease exacerbates [50-52]. Moreover, it has been demonstrated that IL-6 enhances mouse mortality in $P$. aeruginosa pulmonary infections $[35,52,53]$. The $\mathrm{PGE}_{2} / \mathrm{IL}-6$ axis promotes IL-23 (IL-12p40), inhibits IL-12p70, and subsequently induces production of IL-17, the cytokine responsible for exacerbation of chronic inflammatory processes $[52,54,55]$. $\mathrm{PGE}_{2}$ also contributes to the suppression of innate immunity during chronic mucosal bacterial infections [56-58].

Taken together, our finding partially explain why neutrophils infiltrating chronically infected tissue (e.g., CF airways) are not able to clear $P$. aeruginosa biofilm and contribute to tissue damage by releasing their dangerous cargo, as demonstrated in clinical studies [59]. This in vitro study showed that biofilm matrix components (LPS, DNA, EPS), without direct contact of bacteria and with phagocytes, stimulated release of proinflammatory mediators. Therefore, the interaction between biofilm and BAN/BAMs might favor chronic inflammation rather than effective killing of pathogens ("frustrated phagocytosis") and resolution of inflammation (Fig. 9).

Acknowledgements We would like to thank Angelika Peruń from Chair of Immunology, Medical College, Jagiellonian University, for technical support.

Author contributions Conceived and designed the experiments: JM, MS, performed the experiments: MCL, MW, GM, analyzed the data: MCL, MW, MS, JM, contributed reagents/materials/analysis tools: MCL, MW, AMŻ, DM, SG, AG, and wrote the paper: JM, BC. All authors read and approved the final manuscript.

Funding This study was supported by Grants from the Jagiellonian University Medical College (Grant no. K/ZDS/006147) and National Science Centre, Poland (Grant nos. NN401547040 and 2017/27/B/ NZ6/001772). The funders had no role in study design, data collection and analysis, decision to publish, or preparation of the manuscript.

Data availability The data that support the findings of this study are available from the corresponding author upon reasonable request.

\section{Compliance with ethical standards}

Conflict of interest The authors declare that they have no competing interests.
Ethics approval and consent to participate All animal procedures were conducted according to the guidelines and with the approval of the I Local Committee on the Ethics of Animal Experiments of Jagiellonian University.

Consent for publication Not applicable.

Open Access This article is distributed under the terms of the Creative Commons Attribution 4.0 International License (http://creativeco mmons.org/licenses/by/4.0/), which permits unrestricted use, distribution, and reproduction in any medium, provided you give appropriate credit to the original author(s) and the source, provide a link to the Creative Commons license, and indicate if changes were made.

\section{References}

1. Lorè NI, Cigana C, De Fino I, Riva C, Juhas M, Schwager S, et al. Cystic fibrosis-niche adaptation of Pseudomonas aeruginosa reduces virulence in multiple infection hosts. PLoS One. 2012;7(4):e35648. https://doi.org/10.1371/journal.pone.0035648.

2. Wolcott RD, Rhoads DD, Dowd SE. Biofilms and chronic wound inflammation. J Wound Care. 2008;17(8):333-41. https://doi. org/10.12968/jowc.2008.17.8.30796.

3. Watters C, DeLeon K, Trivedi U, Griswold JA, Lyte M, Hampel $\mathrm{KJ}$, et al. Pseudomonas aeruginosa biofilms perturb wound resolution and antibiotic tolerance in diabetic mice. Med Microbiol Immunol (Berl). 2013;202(2):131-41. https://doi.org/10.1007/ s00430-012-0277-7.

4. Cigana C, Curcurù L, Leone MR, Ieranò T, Lorè NI, Bianconi I, et al. Pseudomonas aeruginosa exploits lipid A and muropeptides modification as a strategy to lower innate immunity during cystic fibrosis lung infection. PLoS One. 2009;4(12):e8439. https://doi. org/10.1371/journal.pone.0008439.

5. Alhede M, Bjarnsholt T, Givskov M, Alhede M. Chapter onePseudomonas aeruginosa biofilms: mechanisms of immune evasion. In: Sariaslani S, Gadd GM, editors. Advances in applied microbiology. San Diego: Academic Press; 2014. pp. 1-40.

6. Hänsch GM. Host defence against bacterial biofilms: "Mission Impossible"? ISRN Immunol. 2012. https://doi. org/10.5402/2012/853123.

7. Marcinkiewicz J, Strus M, Pasich E. Antibiotic resistance: a "dark side" of biofilm-associated chronic infections. Pol Arch Med Wewn. 2013;123(6):309-13.

8. Hirschfeld J. Dynamic interactions of neutrophils and biofilms. J Oral Microbiol. 2014;6(1):26102. https://doi.org/10.3402/jom. v6.26102.

9. Jensen P, Bjarnsholt T, Phipps R, Rasmussen TB, Calum H, Christoffersen L, et al. Rapid necrotic killing of polymorphonuclear leukocytes is caused by quorum-sensing-controlled production of rhamnolipid by Pseudomonas aeruginosa. Microbiol. 2007;153(5):1329-38. https://doi.org/10.1099/ mic.0.2006/003863-0. doi.

10. Ghafoor A, Hay ID, Rehm BHA. Role of exopolysaccharides in Pseudomonas aeruginosa biofilm formation and architecture. Appl Environ Microbiol. 2011;77(15):5238-46. https://doi. org/10.1128/aem.00637-11.

11. Fong JNC, Yildiz FH. Biofilm matrix proteins. Microbiol Spectr. 2015. https://doi.org/10.1128/microbiolspec.MB-0004-2014.

12. Wang S, Liu X, Liu H, Zhang L, Guo Y, Yu S, et al. The exopolysaccharide Psl-eDNA interaction enables the formation of a biofilm skeleton in Pseudomonas aeruginosa. Environ Microbiol 
Rep. 2015;7(2):330-40. https://doi.org/10.1111/1758-2229.12252

13. Ciornei CD, Novikov A, Beloin C, Fitting C, Caroff M, Ghigo $\mathrm{J}-\mathrm{M}$, et al. Biofilm-forming Pseudomonas aeruginosa bacteria undergo lipopolysaccharide structural modifications and induce enhanced inflammatory cytokine response in human monocytes. Innate Immunity. 2010;16(5):288-301. https://doi. org/10.1177/1753425909341807.

14. Luo F, Sun X, Qu Z, Zhang X. Salmonella typhimurium-induced M1 macrophage polarization is dependent on the bacterial $\mathrm{O}$ antigen. World J Microbiol Biotechnol. 2016;32(2):22. https:// doi.org/10.1007/s11274-015-1978-z.

15. Marcinkiewicz J, Stręk P, Strus M, Głowacki R, Ciszek-Lenda M, Zagórska-Świeży K, et al. Staphylococcus epidermidis and biofilm-associated neutrophils in chronic rhinosinusitis. A pilot study. Int J Exp Pathol. 2015;96(6):378-86. https://doi. org/10.1111/iep.12156.

16. SenGupta S, Hittle LE, Ernst RK, Uriarte SM. Mitchell TC6.A Pseudomonas aeruginosa hepta-acylated lipid A variant associated with cystic fibrosis selectively activates human neutrophils. J Leukoc Biol. 2016;100(5):1047-59.

17. Shih CC1, Liu PY, Chen JH, Liao MH, Hsieh CM, Ka SM, et al. Macrophage expression of E3 ubiquitin ligase Grail protects mice from lipopolysaccharide-induced hyperinflammation and organ injury. PLoS One. 2018;13(12):e0208279. https://doi. org/10.1371/journal.pone.0208279.

18. Deffert C, Carnesecchi S, Yuan H, Rougemont AL, Kelkka $\mathrm{T}$, Holmdahl R, et al. Hyperinflammation of chronic granulomatous disease is abolished by NOX2 reconstitution in macrophages and dendritic cells. J Pathol. 2012;228(3):341-50. https://doi.org/10.1002/path.4061.

19. Kato T, Terui T, Zhen YX, Tagami H. Influence of staphylococcal lipoteichoic acid on the frustrated phagocytosis of neutrophils against opsonized corneocytes. Exp Dermatol. 1993;2(4):171-4.

20. Sadowska B, Więckowska-Szakiel M, Paszkiewicz M, Różalska B. The immunomodulatory activity of Staphylococcus aureus products derived from biofilm and planktonic cultures. Arch Immunol Ther Exp (Warsz). 2013;61(5):413-20. https://doi. org/10.1007/s00005-013-0240-3.

21. Fridlender ZG, Sun J, Kim S, Kapoor V, Cheng G, Ling L, et al. Polarization of tumor-associated neutrophil phenotype by TGF- $\beta$ : "N1" versus “N2" TAN. Cancer Cell. 2009;16(3):183-94. https:// doi.org/10.1016/j.ccr.2009.06.017.

22. Mantovani A. Macrophages, neutrophils, and cancer: a double edged sword. New J Sci. 2014. https://doi.org/10.1155/2014/27194 0 .

23. Strus M, Walczewska M, Machul A, Mikołajczyk D, Marcinkiewicz J. Taurine haloamines and biofilm. Part I: antimicrobial activity of taurine bromamine and chlorhexidine against biofilm forming Pseudomonas aeruginosa. Adv Exp Med Biol. 2015;803:121-32.

24. Strus M, Mikołajczyk D, Machul A, Heczko PB, Chronowska A, Stochel G, et al. Effects of the selected iminosugar derivatives on Pseudomonas aeruginosa biofilm formation. Microb Drug Resist. 2016;22(8):638-45. https://doi.org/10.1089/mdr.2015.0231.

25. Reuter M, Mallett A, Pearson BM, van Vliet AHM. Biofilm formation by Campylobacter jejuni is increased under aerobic conditions. Appl Environ Microbiol. 2010;76(7):2122-8. https://doi. org/10.1128/aem.01878-09.

26. Machul A, Mikołajczyk D, Regiel-Futyra A, Heczko PB, Strus M, Arruebo M, et al. Study on inhibitory activity of chitosanbased materials against biofilm producing Pseudomonas aeruginosa strains. J Biomater Appl. 2015;30(3):269-78. https://doi. org/10.1177/0885328215578781.
27. Westphal O, Jann K. Bacterial lipopolysaccharides. Extraction with phenol-water and further applications of the procedure. In: BeMiller JN, Shafizadeh F, editors. Methods in carbohydrate chemistry. New York: New York: Academic Press; 1965. pp. 83-91.

28. Górska S, Jachymek W, Rybka J, Strus M, Heczko PB, Gamian A. Distinct immunomodulation of bone marrow-derived dendritic cell responses to Lactobacillus plantarum WCFS1 by two different polysaccharides isolated from Lactobacillus rhamnosus LOCK 0900. Appl Environ Microbiol. 2014;80(20):6506. https ://doi.org/10.1128/AEM.02104-14.

29. Dubois M, Giller KA, Rebers PA, Smith FA. Colorimetric method for determination of sugars and related substances. Anal Chem. 1956;28:350-6.

30. Marcinkiewicz J, Grabowska A, Lauterbach R, Bobek M. Differential effects of pentoxifylline, a non-specific phosphodiesterase inhibitor, on the production of IL-10, IL-12 p40 and p35 subunits by murine peritoneal macrophages. Immunopharmacology. 2000;49(3):335-43.

31. Ding AH, Nathan CF, Stuehr DJ. Release of reactive nitrogen intermediates and reactive oxygen intermediates from mouse peritoneal macrophages. Comparison of activating cytokines and evidence for independent production. J Immunol. 1988;141(7):2407-12.

32. Murray PJ, Allen JE, Biswas SK, Fisher EA, Gilroy DW, Goerdt $S$, et al. Macrophage activation and polarization: nomenclature and experimental guidelines. Immunity. 2014;41(1):14-20. https ://doi.org/10.1016/j.immuni.2014.06.008.

33. Montanaro L, Poggi A, Visai L, Ravaioli S, Campoccia D, Speziale P, et al. Extracellular DNA in biofilms. Int J Artif Organs. 2011;34(9):824-31. https://doi.org/10.5301/ijao.5000051.

34. Hentzer M, Teitzel GM, Balzer GJ, Heydorn A, Molin S, Givskov $\mathrm{M}$, et al. Alginate overproduction affects Pseudomonas aeruginosa biofilm structure and function. J Bacteriol. 2001;183(18):5395401. https://doi.org/10.1128/jb.183.18.5395-5401.2001.

35. Itagaki K, Adibnia Y, Sun S, Zhao C, Sursal T, Chen Y, et al. Bacterial DNA induces pulmonary damage via TLR9 through cross-talk with neutrophils. Shock. 2011;36(6):548-52. https:// doi.org/10.1097/SHK.0b013e3182369fb2.

36. Harm S, Gabor F, Hartmann J. Low-dose polymyxin: an option for therapy of Gram-negative sepsis. Innate Immunity. 2016;22(4):274-83. https://doi.org/10.1177/1753425916639120.

37. Bruscia EM, Bonfield TL. Innate and adaptive immunity in cystic fibrosis. Clin Chest Med. 2016;37(1):17-29. https://doi. org/10.1016/j.ccm.2015.11.010.

38. Sousa A, Pereira M. Pseudomonas aeruginosa diversification during infection development in cystic fibrosis lungs-a review. Pathogens. 2014;3(3):680. https://doi.org/10.3390/pathogens3 030680.

39. Hogardt M, Heesemann J. Adaptation of Pseudomonas aeruginosa during persistence in the cystic fibrosis lung. Int J Med Microbiol. 2010;300(8):557-62. https://doi.org/10.1016/j.ijmm.2010.08.008.

40. Boles BR, Thoendel M, Singh PK. Rhamnolipids mediate detachment of Pseudomonas aeruginosa from biofilms. Mol Microbiol. 2005;57(5):1210-23. https://doi.org/10.111 1/j.1365-2958.2005.04743.x.

41. Kragh KN, Alhede M, Jensen P, Moser C, Scheike T, Jacobsen $\mathrm{CS}$, et al. Polymorphonuclear leukocytes restrict growth of $\mathrm{Pseu-}$ domonas aeruginosa in the lungs of cystic fibrosis patients. Infect Immun. 2014;82(11):4477-86. https://doi.org/10.1128/iai.01969 -14 .

42. Kruger P, Saffarzadeh M, Weber ANR, Rieber N, Radsak M, von Bernuth H, et al. Neutrophils: between host defence, immune modulation, and tissue injury. PLoS Pathog. 2015;11(3):e1004651. https://doi.org/10.1371/journal.ppat.1004651. 
43. Stressmann FA, Rogers GB, Marsh P, Lilley AK, Daniels TWV, Carroll MP, et al. Does bacterial density in cystic fibrosis sputum increase prior to pulmonary exacerbation? J Cyst Fibros. 2011;10(5):357-65. https://doi.org/10.1016/j.jcf.2011.05.002.

44. Labiris NR, Nahmias C, Freitag AP, Thompson ML, Dolovich MB. Uptake of ${ }^{18}$ fluorodeoxyglucose in the cystic fibrosis lung: a measure of lung inflammation? Eur Respir J. 2003;21(5):848-54. https://doi.org/10.1183/09031936.03.00065102.

45. Marcinkiewicz J, Strus M, Walczewska M, Machul A, Mikołajczyk D. Influence of taurine haloamines ( $\mathrm{TauCl}$ and TauBr) on the development of Pseudomonas aeruginosa biofilm: a preliminary study. Adv Exp Med Biol. 2013;775:269-83.

46. Senturk S, Ulusoy S, Bosgelmez-Tinaz G, Yagci A. Quorum sensing and virulence of Pseudomonas aeruginosa during urinary tract infections. J Infect Dev Ctries. 2012;6(6):501-7. https://doi. org/10.3855/jidc. 2543 .

47. Pier GB. Pseudomonas aeruginosa lipopolysaccharide: a major virulence factor, initiator of inflammation and target for effective immunity. Int J Med Microbiol. 2007;297(5):277-95. https://doi. org/10.1016/j.ijmm.2007.03.012.

48. Fuxman Bass JI, Russo DM, Gabelloni ML, Geffner JR, Giordano M, Catalano M, et al. Extracellular DNA: a major proinflammatory component of Pseudomonas aeruginosa biofilms. J Immunol. 2010;184(11):6386-95. https://doi.org/10.4049/jimmunol.09016 40.

49. Leid JG, Willson CJ, Shirtliff ME, Hassett DJ, Parsek MR, Jeffers AK. The exopolysaccharide alginate protects Pseudomonas aeruginosa biofilm bacteria from IFN- $\gamma$-mediated macrophage killing. J Immunol. 2005;175(11):7512-8. https://doi.org/10.4049/ jimmunol.175.11.7512.

50. Inoue H, Takamori M, Shimoyama Y, Ishibashi H, Yamamoto $\mathrm{S}$, Koshihara Y. Regulation by PGE2 of the production of interleukin-6, macrophage colony stimulating factor, and vascular endothelial growth factor in human synovial fibroblasts. Br J Pharmacol. 2002;136(2):287-95. https://doi.org/10.1038/sj.bjp.07047 05 .

51. Carpagnano GE, Barnes PJ, Geddes DM, Hodson ME, Kharitonov SA. Increased leukotriene B4 and interleukin-6 in exhaled breath condensate in cystic fibrosis. Am J Respir Crit Care Med. 2003;167(8):1109-12. https://doi.org/10.1164/rccm.20020 3-1790C.
52. Bérubé J, Roussel L, Nattagh L, Rousseau S. Loss of cystic fibrosis transmembrane conductance regulator function enhances activation of $\mathrm{p} 38$ and ERK MAPKs, increasing interleukin-6 synthesis in airway epithelial cells exposed to Pseudomonas aeruginosa. J Biol Chem. 2010;285(29):22299-307. https://doi.org/10.1074/ jbc.M109.098566.

53. Guillemot L, Medina M, Pernet E, Leduc D, Chignard M, Touqui L, et al. Cytosolic phospholipase A2 $\alpha$ enhances mouse mortality induced by Pseudomonas aeruginosa pulmonary infection via interleukin 6. Biochimie. 2014;107:95-104. https://doi. org/10.1016/j.biochi.2014.08.018.

54. Kaliński P, Vieira PL, Schuitemaker JHN, de Jong EC, Kapsenberg ML. Prostaglandin E2 is a selective inducer of interleukin-12 p40 (IL-12p40) production and an inhibitor of bioactive IL-12p70 heterodimer. Blood. 2001;97(11):3466-9. https://doi.org/10.1182/ blood.V97.11.3466.

55. Yamamoto M, Yoshizaki K, Kishimoto T, Ito H. IL-6 Is required for the development of Th1 cell-mediated murine colitis. J Immunol. 2000;164(9):4878-82. https://doi.org/10.4049/jimmu nol.164.9.4878.

56. Kozawa O, Suzuki A, Tokuda H, Kaida T, Uematsu T. Interleukin-6 synthesis induced by prostaglandin E2: cross-talk regulation by protein kinase C. Bone. 1998;22(4):355-60. https://doi. org/10.1016/s8756-3282(97)00293-7.

57. Sadikot RT, Zeng H, Azim AC, Joo M, Dey SK, Breyer RM, et al. Bacterial clearance of Pseudomonas aeruginosa is enhanced by the inhibition of COX-2. Eur J Immunol. 2007;37(4):1001-9. https://doi.org/10.1002/eji.200636636.

58. Agard M, Asakrah S, Morici L. PGE2 suppression of innate immunity during mucosal bacterial infection. Front Cell Infect Microbiol. 2013. https://doi.org/10.3389/fcimb.2013.00045.

59. Rada B. Interactions between neutrophils and Pseudomonas aeruginosa in cystic fibrosis. Pathogens. 2017;6(1):10. https://doi. org/10.3390/pathogens6010010.

Publisher's Note Springer Nature remains neutral with regard to jurisdictional claims in published maps and institutional affiliations. 